\author{
Contato \\ Largo de São Francisco de Paula, n. 1 - sala 311 \\ 20051-070 - Rio de Janeiro - R \\ victor.a.melo@uol.com.br
}

\section{ENFRENTANDO OS DESAFIOS DO MAR: A NATAÇÃO NO RIO DE JANEIRO DO SÉCULO XIX (ANOS 1850-1890)*}

\author{
Victor Andrade de Melo** \\ Universidade Federal do Rio de Janeiro
}

\title{
Resumo
}

Este estudo tem por objetivo discutir a conformação da prática da natação no Rio de Janeiro do século XIX, procurando desvendar suas distintas facetas, os diversos sentidos e significados a ela atribuídos, tendo em conta que o tema nos permite lançar um olhar para um conjunto de importantes dimensões da sociedade fluminense no período em tela. Para alcance do objetivo, fizemos uso de periódicos editados na cidade, tomando os devidos cuidados de entender o publicado como representações que devem ser prospectadas na sua materialidade. Adotamos como recorte temporal o século XIX (anos 1850-1890) não somente por ser o momento no qual o hábito de nadar e a natação esportiva começaram a se conformar na capital do país, mas também em função do quadro contextual em que o costume se delineava, um período marcado por grandes mudanças na cidade, inclusive relacionadas à adesão a ideias de modernidade.

\section{Palavras-chave}

História do esporte - natação - Rio de Janeiro.

* Esta pesquisa contou com apoio da Faperj e CNPq.

** Pós-doutorado em História, professor associado, Departamento de Didática, Faculdade de Educação. 
rev. hist. (São Paulo), n. 172, p. 299-334, jan.jun., 2015 http://dx.doi.org/10.11606/issn.2316-9141.rh.2015.98755

\title{
FACING THE SEA \\ CHALLENGES: \\ SWIMMING IN \\ $19^{\text {TH }}$ CENTURY \\ RIO DE JANEIRO \\ (1850'S-1890'S)
}

Contact

Largo de São Francisco de Paula, n. 1 - sala 311

20051-070 - Rio de Janeiro - R

Victor Andrade de Melo

victor.a.melo@uol.com.br

\begin{abstract}
This study aims to discuss the conformation of the swimming practice in $19^{\text {th }}$ century Rio de Janeiro, seeking to unveil its different facets, the various meanings attributed to it, considering that the subject could allow us to better understand some important dimensions of fluminense society in the period. To reach the goal, we used as sources newspapers and magazines published in the city, trying to understand the positions as representations that must be prospected in its materiality. We choose to investigate the $19^{\text {th }}$ century (1850's-1890's) not only for being the moment in which the custom of swimming began to settle in the capital, but also due to the contextual framework, a period marked by changes in the city, including on adherence to ideas of modernity.
\end{abstract}

\section{Keywords}

Sport history - swimming - Rio de Janeiro. 


\section{Introdução}

Março de 1871. Bentinho e Capitu uma vez mais deixam sua casa na Glória para jantar na residência de Escobar e Sancha, na praia do Flamengo. Em certo momento da noite, na janela a ouvir o barulho do mar em ressaca (como os olhos de Capitu, conforme sugeria o protagonista), perdido em pensamentos (inclusive elucubrações sobre sua relação com Sancha), Bentinho percebe o amigo se aproximar:

- O mar amanhã está de desafiar a gente, disse-me a voz de Escobar, ao pé de mim.

- Você entra no mar amanhã?

- Tenho entrado com mares maiores, muito maiores. Você não imagina o que é um bom mar em hora bravia. É preciso nadar bem, como eu, e ter estes pulmões disse ele batendo no peito, e estes braços; apalpa.

Bentinho assume que, a princípio, em Sancha lembrou quando apalpou o braço de Escobar. Todavia, logo uma sensação constrangedora lhe acometeu: "achei-os mais grossos e fortes que os meus, e tive-lhes inveja; acresce que sabiam nadar".

No retorno à Glória, ainda fantasiando a relação com Sancha, inebriado pelo forte ruído do oceano ("a ressaca era grande e, à distância, viam-se crescer as ondas"), Bentinho se dá conta do incômodo que lhe causava a figura de Escobar, materializado numa fotografia que possuía em casa.

No dia seguinte, anunciar-se-ia o fim trágico. Um escravo trouxe a notícia fúnebre: "- Para ir lá... sinhô nadando, sinhô morrendo". A caminho da residência do casal amigo, Bentinho especula o que pode ter ocorrido: Escobar arriscara-se muito no mar e não resistiu. Soube a posteriori que "as canoas que tentaram o ajudar mal conseguiram recuperar o cadáver". O que se segue é o acentuar de seu drama, já bem conhecido, por se tratar Dom Casmurro de um dos mais importantes romances da literatura brasileira. ${ }^{1}$

Entre tantas leituras possíveis, podemos ver na obra um embate entre modelos de performance masculina. A postura de Escobar se adequa a um conjunto hegemônico de compreensões sobre os papéis sociais masculinos. Já Bentinho: "Fraco desde o início, (...) é uma vergonha como homem. É o

\footnotetext{
1 O romance foi escrito em 1899. Usa-se aqui a versão disponível em: $<$ http://www.dominiopublico.gov.br/download/texto/bv00180a.pdf>. Acesso em: 15/09/2014. Os trechos citados se encontram entre as páginas 89 e 91.
} 
oposto da masculinidade integrada, da hombridade, da virilidade, da criatividade. A masculinidade dele é insultuosa".2

O que para nós neste artigo vale ressaltar é como Machado de Assis, na composição de seu personagem "másculo", o destaca, entre outras características, pela compleição muscular e pelo hábito de praticar a natação. $\mathrm{O}$ comerciante e empreendedor Escobar enfrenta mares bravios com seus bons pulmões e braços fortes. Morre não por covardia, mas, sim, por ousadia. Bentinho, ao contrário, toma ciência de sua fraqueza e inveja o amigo: sabese débil em muitos sentidos.

Podemos também considerar que se trata da dramatização de um embate entre o homem da tradição bacharelesca, que só se dedica às coisas da "mente" e do "espírito", e o novo burguês, que expressa com seu corpo os comportamentos e posturas que marcam uma personalidade disposta a aceitar desafios. Enfrentar o oceano com seus próprios braços é um sinal definidor do perfil desse homem. No romance, aliás, o mar é uma metáfora dos conflitos que o protagonista vai enfrentar (sem grande sucesso, aliás).

Nesse pequeno trecho de Dom Casmurro, breve, mas relevante do ponto de vista da trama, vemos uma representação da presença da natação na sociedade fluminense do século XIX. ${ }^{3}$ Em 1877, assim se definiu a prática em $O$ Apóstolo, um importante periódico católico: "A arte que tem o nome de natação consiste em suster o corpo sobre a água e movê-lo em qualquer direção". Numa longa reflexão, o autor chama a atenção para os desafios que existem para quem deseja nadar, descrevendo os movimentos de cabeça, pernas e braços necessários para executar com sucesso a tarefa. A essa altura, na verdade, a modalidade já tinha uma trajetória de cerca de 20 anos na cidade, bem como começava a dar passos mais seguros no tocante a sua popularização.

Este estudo tem por objetivo discutir a conformação da prática da natação no Rio de Janeiro do século XIX, procurando desvendar suas distintas facetas, os diversos sentidos e significados a ela atribuídos, tendo em conta que o tema nos permite lançar um olhar para um conjunto de importantes dimensões da sociedade fluminense no período em tela. Para alcance do objetivo, fizemos uso de periódicos editados na cidade, tomando os devidos

\footnotetext{
2 BYINGTON, Carlos Amadeu Botelho. Dom Casmurro no divã: um estudo da psicologia simbólica junguiana. In: CARVALHO, Luiz Fernando (org.). O processo de Capitu. Rio de Janeiro: Casa da Palavra, 2008, p. 25.

3 Vale destacar que outros literatos do século XIX inseriram a modalidade em suas obras: Raul Pompeia (O Ateneu, 1888), Aluísio Azevedo (O Coruja, 1890), Artur Azevedo (Capital Federal, 1897).

${ }^{4} O$ Apóstolo, 20/07/1877, p. 4.
} 
cuidados de entender o publicado como representações que devem ser prospectadas na sua materialidade. ${ }^{5}$

Adotamos como recorte temporal o século XIX (anos 1850-1890) não somente por ser o momento no qual o hábito de nadar e a natação esportiva começaram a se conformar no Rio de Janeiro, mas também em função do quadro contextual em que o costume se delineava, um período marcado por grandes mudanças na cidade, inclusive relacionadas à adesão a ideias de modernidade.

Vale comentar que a despeito de ser a natação uma prática muito presente no cotidiano do Rio de Janeiro, no passado e no presente, não há muitos esforços que procuram prospectar seu delineamento no período em tela, ao contrário do cenário internacional, onde já chamou a atenção de muitos pesquisadores. ${ }^{6}$ No que tange à capital do Brasil à época, há apenas algumas breves referências em alguns estudos, como as que se encontram no esclarecedor artigo de Barickman. ${ }^{7}$

\section{Os banhos, o mar, a natação}

No Rio de Janeiro dos primeiros anos da década de 1850, diversas são as evidências de que estava em curso um processo de ampliação das perspectivas do uso do mar, que passou a ser mais intensamente ocupado com atividades que não as de natureza eminentemente econômica (navegação, pesca, transporte de produtos e pessoas). Por vezes, esse tema foi mesmo tratado com uma ironia diagnóstica, como podemos ver no Correio Mercantil, na seção "Pacotilha", na qual eram publicadas notícias do exterior e do país, em muitas ocasiões de forma bem humorada: "Felicito com entusiasmo aos patuscos que a certa hora se banham no mar das Areias de Espanha, pelo imenso progresso que tem adquirido na arte de nadar".

$\mathrm{O}$ autor registrava o aumento do hábito dos banhos de mar na já não mais existente praia da Lapa, região central da cidade (ia do Parque Público

\footnotetext{
${ }_{5}^{5}$ LUCA, Tania Regina de. História do, no e por meio dos periódicos. In: PINSKY, Carla Bassanezi (org.). Fontes históricas. São Paulo: Contexto, 2005, p. 111-53.

6 Ver, por exemplo: TERRET, Thierry. Naissance et diffusion de la natation sportive. Paris: L'Harmattan, 1994; LOVE, Christopher. A social history of swimming in England, 1800 - 1918: splashing in the serpentine. Londres: Routledge, 2007.

7 BARICKMAN, B. J. O banho de mar no Rio de Janeiro no século XIX e no começo do século XX. Arizona, 2010.

${ }^{8}$ Nessa ocasião, o autor provavelmente se tratava de Manuel Antônio de Almeida, redator do Correio Mercantil e autor de Memórias de um Sargento de Milícias.

9 Correio Mercantil, 19/03/1854, p. 1.
} 
rev. hist. (São Paulo), n. 172, p. 299-334, jan.-jun., 2015 http://dx.doi.org/10.11606/issn.2316-9141.rh.2015.98755
Victor Andrade de Melo

Enfrentando os desafios do mar: a natação no Rio de Janeiro do século XIX (anos 1850-1890)

ao largo da Glória). Nesse mesmo ano, na satírica seção "Visita das Priminhas", no Periódico dos Pobres, também se identifica o costume; nadar era usado como sinônimo de entrar e movimentar-se no oceano. ${ }^{10}$ Nesse momento, persistiam muitas dúvidas e preocupações quanto à propriedade desses novos costumes.

De toda forma, já se tornavam públicas posições favoráveis. Em 1856, José de Alencar, na primeira página do Diário do Rio de Janeiro, ao comentar a utilidade de se estabelecer um código municipal de posturas, sugeriu a necessidade de criação de escolas de natação, inseridas em uma maior dinamização dos divertimentos públicos, a seu ver fundamentais para o avanço dos costumes na sociedade da Corte. Dois dias depois, retoma o tema o articulando com as ideias de saúde e higiene:

\footnotetext{
Não são também as medidas preventivas unicamente que conservam a saúde pública: convém dar aos moradores alimentos puros, passeios agradáveis, exercícios saudáveis, como os que ele pode achar em escolas de natação, de equitação, em banhos de mar, para os quais a nossa cidade oferece tanta vantagem. ${ }^{11}$
}

O desenvolvimento da prática da natação se articulava com questões mais amplas que permeavam o cotidiano do Rio de Janeiro daqueles meados de século XIX, notadamente a necessidade de ordenação urbana de uma capital que cada vez mais ocupava um papel de centralidade na nação, em um momento marcado pela melhor estruturação da burocracia estatal e de diversificação econômica. ${ }^{12}$

Uma parte das lideranças nacionais assumia a necessidade de melhorar as condições de salubridade, dotando o Rio de Janeiro de uma mais adequada estrutura de distribuição da água e de captura e dispensa do esgoto, de coleta de lixo, de atendimento de saúde, inclusive para fazer frente às constantes epidemias que acometiam a cidade: cólera, febre amarela, tifo, entre outras. ${ }^{13}$

Uma das medidas entabuladas nesse novo cenário foi o estímulo do hábito do banho, entre os quais aqueles que faziam uso do mar, até mesmo

\footnotetext{
${ }^{10}$ Periódico dos Pobres, 23/11/1854, p. 1.

${ }^{11}$ Diário do Rio de Janeiro, 04/04/1856, p. 1.

12 SCHWARCZ, Lilia Moritz. As barbas do imperador. São Paulo: Companhia das Letras, 1998; NEVES, Lucia Bastos Pereira das. A vida política. In: SILVA, Alberto da Costa (coord.). História do Brasil nação (18082010), vol. 1 - Crise colonial e independência (1808-1830). Rio de Janeiro: Objetiva, 2011, p. 75-114.

${ }^{13}$ MARCILIO, Maria Luiza. Mortalidade e morbidade da cidade do Rio de Janeiro imperial. Revista de História, São Paulo, n. 127-128, ago-dez 1992; jan.-jul. 1993, p. 53-68; CHALHOUB, Sidney. Cidade febril: cortiços e epidemias na Corte imperial. São Paulo: Companhia das Letras, 2006.
} 
rev. hist. (São Paulo), n. 172, p. 299-334, jan.-jun., 2015 http://dx.doi.org/10.11606/issn.2316-9141.rh.2015.98755
Victor Andrade de Melo

Enfrentando os desafios do mar: a nataç̃óo no Rio de Janeiro do século XIX (anos 1850-1890)

porque a deficiente distribuição de água dificultava a sua adoção cotidiana. ${ }^{14}$ Até mesmo por isso, tornou-se mais comum a preocupação com a limpeza das praias, inclusive com a extinção do costume de se atirar os detritos no litoral ao fim do dia, tarefa normalmente desempenhada por escravos. ${ }^{15}$ Uma visitante francesa que esteve no Brasil nas décadas de 1850/1860, Adèle Toussaint-Samson, chegou a observar, por ocasião de sua chegada à cidade:

As margens da baía não são mais do que um vaso infecto, onde detritos de toda espécie apodrecem exalando emanações nauseabundas. Essa foi nossa primeira desilusão. Aquelas praias, que de longe pareciam tão belas e tão perfumadas, eram o receptáculo das imundices da cidade. Depois ela foi saneada por esgotos. ${ }^{16}$

A partir da década de 1850, progressivamente foram apresentados os benefícios e as potencialidades dos banhos de mar. ${ }^{17}$ Na Revista Popular, um periódico de informação geral, cujo intuito era instruir de forma mais acessível e divertida, na seção "Higiene", em 1859, se publica um amplo artigo sobre a importância do hábito, "o principal meio de saúde e de frescura". ${ }^{18}$ Para o autor, o costume daria "às pessoas, que os podem suportar uma força e atividade notáveis. Sua ação sobre todas as organizações é tônica, salutar e refrigerante".19

Em boa medida, o desenvolvimento do hábito da natação, especialmente nos seus momentos iniciais, tem relação com essa vulgarização dos banhos de mar. $^{20}$ Bem registram esse aspecto dois visitantes que no Rio de Janeiro dos anos 1850 se estabeleceram. Em seu relato de 1857, James Cooley Fletcher e Daniel Parish Kidder observam que, no verão, a praia do Flamengo recebia grande número de frequentadores - homens, mulheres e crianças, que se banhavam muito cedo, em meio a um clima de diversão e festa. De acordo com seu olhar, "Os cavalheiros são obrigados pelo regulamento da

\footnotetext{
${ }^{14}$ Sobre a articulação entre as ideias de higiene, saúde e a prescrição de banhos, ver: VIGARELLO, Georges. O limpo e o sujo. A higiene do corpo desde a Idade Média. Lisboa: Fragmentos, 1988.

${ }^{15}$ Observa-se que antes o lixo era jogado no Campo de Santana, até ser proibido por um dos vice-reis, que indicou o mar como local adequado para a deposição (NEEDELL, Jeffrey D. Belle Époque tropical. São Paulo: Companhia das Letras, 1993).

${ }^{16}$ TOUSSAINT-SAMSON, Adèle. Uma parisiense no Brasil. Rio de Janeiro: Editora Capivara, 2003, p. 74.

${ }^{17}$ De toda forma, há evidências de que, na primeira metade do século XIX, havia gente se banhando nas praias cariocas. Para mais informações, ver BARICKMAN, B. J., op. cit.

${ }^{18}$ Revista Popular, 1859, p. 234.

${ }^{19}$ Revista Popular, 1859, p. 236.

${ }^{20}$ Para uma visão da difusão dos banhos de mar no cenário europeu, ver CORBIN, Alain. $O$ território do vazio. A praia e o imaginário ocidental. São Paulo: Companhia das Letras, 1989. No caso do Rio de Janeiro, ver BARICKMAN, B. J., op. cit.
} 
rev. hist. (São Paulo), n. 172, p. 299-334, jan.-jun., 2015 http://dx.doi.org/10.11606/issn.2316-9141.rh.2015.98755
Victor Andrade de Melo

Enfrentando os desafios do mar: a natação no Rio de Janeiro do século XIX (anos 1850-1890)

polícia a se vestirem decentemente, o que até agora não tem impedido de nadar os que preferem esse exercício às 'duchas' das ondas"..21

Na primeira página do Correio Mercantil, numa edição de outubro de 1856, publicou-se a matéria traduzida "Hidropatia", dedicada a discutir os ganhos e benefícios dessa terapêutica. Para o autor, "A natação no mar é particularmente útil para habituar o corpo a uma demora prolongada na água que possa permitir uma maior absorção de princípios salinos. Deve-se também levar em conta os bons efeitos do exercício". ${ }^{22}$

Os ganhos apontados pela prática da natação eram semelhantes aos dos banhos de mar, destacando-se sua articulação com a questão da saúde e higiene pública. A diferença é que, no tocante à modalidade, em função de sua característica de exercício, sugeria-se haver uma potencialização dos resultados. Era apontada como tonificante e fortificante. Não surpreende que fosse considerada como uma forma de ginástica, inserida no rol das atividades físicas adequadas. ${ }^{23}$

Tendo em vista as possíveis potencialidades da natação, os jornais começaram a não só tentar melhor descrever seus ganhos (para os músculos, para os ossos, para a mente), como também a apresentar receituários para a prática (a exemplo do que ocorria no tocante aos banhos de mar). ${ }^{24} \mathrm{~A}$ modalidade integrava um conjunto de procedimentos ligados ao que os médicos chamavam de hidroterapia, relacionada não só à saúde dos indivíduos, como também à saúde pública. ${ }^{25}$

Em alguns documentos oficiais, vemos também indicações sobre o valor da modalidade. Em 1858, no relatório do presidente da Junta Central da Higiene Pública, ${ }^{26}$ Francisco de Paula Cândido, um dos mais importantes

\footnotetext{
${ }^{21}$ FLETCHER, James Cooley \& KIDDER, Daniel Parish. O Brasil e os brasileiros: esboço histórico e descritivo. Rio de Janeiro: Companhia Editora Nacional, 1941, p. 101.

22 Correio Mercantil, 03/10/1856, p. 1.

${ }^{23}$ Para mais informações sobre a difusão da ginástica no Rio de Janeiro do século XIX, ver: MELO, Victor Andrade de \& PERES, Fabio de Faria. A gymnastica nos tempos do Império. Rio de Janeiro: 7 Letras/Faperj, 2014.

${ }^{24}$ Ver, por exemplo, $O$ Globo, 08/01/1875, p. 2.

${ }^{25}$ Ver, por exemplo, a memória sobre o tema apresentada pelo dr. Carlos Eboli à Academia Imperial de Medicina (Annaes Brasilienses de Medicina, abr 1871, p. 41). O assunto foi também abordado em algumas teses apresentadas na Faculdade de Medicina. Para mais informações, ver: FINOCCHIO, José Luiz. A inserção da educação física/gymnastica no ensino secundário - Imperial Collegio de Pedro II (1837-1889). Tese de doutorado em Educação, Universidade Federal de Mato Grosso do Sul, Campo Grande, 2013.

${ }^{26}$ Criada em 1850, foi uma das principais medidas relacionadas às tentativas de o Estado intervir na melhoria do estado sanitário da capital e do Império em geral.
} 
rev. hist. (São Paulo), n. 172, p. 299-334, jan.jun., 2015 http://dx.doi.org/10.11606/issn.2316-9141.rh.2015.98755
Victor Andrade de Melo

Enfrentando os desafios do mar: a nataç̃óo no Rio de Janeiro do século XIX (anos 1850-1890)

médicos do século XIX, observa-se que, dada a sua importância para a saúde, a "criação de passeios, estabelecimentos de natação, de ginástica etc., são ou devem ser da atribuição de engenheiros". ${ }^{27}$ Nesse mesmo documento, quando se discute como as condições estruturais interferem no propagar da tuberculose, lembra-se que "nada se tem feito no sentido de melhorar a educação física de nossa mocidade: os meios materiais, os passeios, a ginástica, a natação, os exercícios, a água, o ar puro... tudo lhes faltaria" (p. A-G-12).

Por vezes, os esculápios faziam uma indicação mais direta da natação para o trato de doenças. Entre outras ocasiões, o dr. José d'Aquino Fonseca sugeriu que poderia ser útil no tratamento da clorose, espécie de apatia, anemia e letargia. ${ }^{28}$ Já o dr. Kogerer a indica para reduzir os sintomas da constipação crônica. ${ }^{29}$ Não surpreende, assim, que a modalidade integrasse o rol de estratégias oferecidas por casas de saúde de perfis diversos.

No Andaraí Pequeno (atual bairro da Tijuca), Candido Antonio Pessoa de Amorim, comerciante do ramo de tecidos, tendo descoberto nascentes de água mineral, ${ }^{30}$ passou a oferecer na sua chácara quartos para os convalescentes. O proprietário disponibilizava banhos de cachoeira, de chuva, de ducha e de natação. ${ }^{31}$ Vejamos que, se em alguns casos se confundia o nadador com o banhista, em outros, a natação era tida como uma das modalidades de banhos.

Um dos estabelecimentos em que a natação mais foi apresentada como recurso terapêutico foi a Casa de Saúde Dr. Eiras, uma das mais reconhecidas e importantes da cidade. Nos seus primeiros momentos, na segunda metade da década de 1860, quando o dr. Manoel Joaquim Fernandes Eiras a comprou do dr. Antonio José Peixoto, foi mesmo mais uma casa de convalescência e instituto hidroterápico do que um hospital psiquiátrico, como se tornaria mais reconhecida nas décadas finais do século XIX. Na sua publi-

\footnotetext{
${ }^{27}$ CÂNDIDO, Francisco de Paula. Relatório do presidente da Junta Central de Hygiene Pública. In: BRASIL. Ministério do Império. Relatório do ano de 1858, apresentado à Assembleia geral legislativa na $3^{\mathrm{a}}$ sessão da $10^{\mathrm{a}}$ legislatura. (publicado em 1859). Rio de Janeiro: Ministério do Império, 1859, p. A-G-1 - A-G-17. Disponível em: <http://brazil.crl.edu/bsd/bsd/u1731/>. Acesso em: 17/09/2014.

${ }^{28}$ Arquivo Médico Brasileiro, 1848, p. 73-74. Sobre o perfil e importância dos periódicos médicos do século XIX, ver: FERREIRA, Luiz Otávio. Os periódicos médicos e a invenção de uma agenda sanitária para o Brasil (1827-43). História, Ciência, Saúde - Manguinhos. Rio de Janeiro, v. 6, n. 2, 1999, p. 331-351.

${ }^{29}$ O Brazil Médico, 08/01/1891, p. 11.

${ }^{30}$ O Auxiliador da Indústria Nacional, 1872, p. 424.

${ }^{31}$ Diário do Rio de Janeiro, 08/10/1871, p. 4.
} 
cidade, destacando-se aquela publicada no Almanak Laemmert, a modalidade era apresentada como parte do tratamento das "moléstias mentais".

Há ainda outro aspecto pelo qual os facultativos se envolveram com a reflexão sobre a natação: as próprias peculiaridades da modalidade. Isso se referia aos limites físicos do nadador, à preocupação com o choque térmico, à melhor forma de fazer o exercício, principalmente os procedimentos a serem adotados para a recuperação de afogados. Pelo menos desde 1836, o tema circulava por periódicos médicos, como podemos ver no artigo publicado na Revista Médica Fluminense:

Observações e considerações práticas, que estabelecem a possibilidade de revivência, em caso de asfixia e de submersão prolongada, com a aparência de morte, por René Bourgois, D.M.P., médico residente na Casa Real da Legião d'Honra de S. Diniz, e Cavalheiro da Legião d'Honra. ${ }^{32}$

Os afogamentos foram uma grande preocupação da época, uma constante no decorrer do século, frequentemente anunciada nos jornais, relacionada a naufrágios, suicídios ou descuidos. Nessas ocasiões, comumente se destacava algum "herói" que, por sua habilidade de nadar, caía no mar e salvava os que estavam em risco: "Será aqui o lugar de fazer menção da extraordinária dedicação e coragem de um dos passageiros, o Sr. Mello e Mattos, cujo comportamento foi admirável desde o momento do naufrágio até o fim". ${ }^{33}$

Esses heróis eram das mais diversas formas reconhecidos, com agradecimentos públicos, agrados financeiros ou presentes, até mesmo condecorações: "Ao atracar a galeota imperial no arsenal de marinha, cai ao mar o Visconde de Nogueira da Gama, que é salvo pelo nadador Manoel Joaquim Pimenta, a quem o governo concedeu a medalha de distinção de $1^{\text {a }}$ classe" ${ }^{34}$

De fato, o aumento do uso do mar para banhos potencializou o número de afogamentos, tornando a natação ainda mais indicada por questões de segurança. Na verdade, deve-se ter em conta que, se a princípio eram eminentemente considerados como práticas terapêuticas, posteriormente esses costumes se articularam com a nova dinâmica de entretenimento em

\footnotetext{
32 Revista Médica Fluminense, 1836, p. 138.

33 Diário do Rio de Janeiro, 12/10/1846, p. 1.

${ }^{34}$ Novo e completo índice cronológico da história do Brasil, março 1879, p. 275. Pimenta era um comerciante que atuava no ramo de importação e exportação, dono de lojas de fazendas e ferragens.
} 
gestação da cidade, ${ }^{35}$ que por sua vez induzia a uma nova perspectiva de ocupação das praias.

\section{Uma diversão, um mercado}

É importante ter em conta essa faceta da difusão do hábito de nadar, que se articulava com o costume de ir à praia: o fato de se constituir em uma diversão. Havia injunções médicas e pedagógicas que não podem ser desconsideradas, mas o desejo de divertir-se e participar do grande espetáculo público, de fato, muito incentivou a muitos a se envolverem com a modalidade, ${ }^{36}$ seja como praticante, seja como público (notadamente no caso das competições, como veremos mais à frente).

Não surpreende, assim, que a natação fosse citada em outros divertimentos da ocasião. Por exemplo, no carnaval de 1877, no préstito do Club dos Fenianos, sempre destinado a comentar os fatos da sociedade fluminense, o sétimo carro foi dedicado à "concessão do governo a uma companhia de banhos e uma escola de natação". ${ }^{37}$ Já em 1881, no baile do Club dos Argonautas Carnavalescos, houve apresentação de "certas manobras de natação e força muscular". ${ }^{38}$ Não é possível saber exatamente do que se tratava, mas é provável que tenha sido algo de caráter cômico.

Da mesma forma, a modalidade esteve presente em alguns espetáculos de caráter circense, muito apreciados na ocasião. ${ }^{39}$ Em 1878, no Imperial Teatro D. Pedro II, um dos mais importantes da cidade, apresentou-se como grande atração "Mr. W. Watson - o Homem Peixe", anunciado como "O primeiro nadador do mundo", numa performance em que "come, bebe, fuma, joga, faz saltos e muitos outros exercícios difíceis que causam admiração, em um tan-

\footnotetext{
35 Para um panorama dessa dinâmica de entretenimento, ver: MARZANO, Andrea $\mathcal{E}$ MELO, Victor Andrade de (org.). Vida divertida: histórias do lazer no Rio de Janeiro (1830 - 1930). Rio de Janeiro: Apicuri, 2010.

${ }^{36}$ MELO \& PERES, op. cit., procederam a discussão similar no que tange à ginástica na cidade na mesma ocasião.

${ }^{37}$ Diário do Rio de Janeiro, 13/02/1877, p. 2. Em 1877, o governo imperial autorizou o engenheiro italiano Joseph Fogliani a construir, na região da Tijuca, um estabelecimento no qual seriam oferecidas aulas de natação, concedendo também um subsídio para que fosse atendido um conjunto de alunos da rede pública. A despeito de elogiada a iniciativa, causou também muita polêmica por ser considerada, por alguns, como lesiva aos cofres públicos.

${ }^{38}$ Gazeta de Notícias, 30/10/1881, p. 4.

${ }^{39}$ Melo \& Peres, op. cit.
} 
que contendo grande quantidade de água cristalina". ${ }^{40} \mathrm{O}$ artista também se apresentaria no Skating Ring, dessa vez acompanhado de "Ondina, a Rainha d'Água". ${ }^{41}$ Essas proezas encantavam a sociedade da Corte, ávida por novidades.

Um indicador interessante da valorização da prática é sua inserção em anúncios de casas para alugar. Em 1879, informava-se que uma chácara dispunha de um "tanque para natação".42 Em 1881, uma propriedade chamada Parque Cockrane apresentou como destaque o fato de possuir "banheiros para natação". ${ }^{33}$ Situações semelhantes se observam no decorrer do século, normalmente grandes terrenos localizados em bairros ainda rurais, como Laranjeiras e Tijuca, ou nas imediações da região central.

Empreendimentos imobiliários que aspiravam se apresentar como modernos passaram a inserir instalações de banhos e natação em seus projetos. Em 1857, autorizada pelo governo imperial, a Companhia Arquitetônica, fundada por Francisco José Fialho, anunciava o intuito de construir

Jardins e parques públicos com restauradores, cafés, banhos, pavilhões, e salas com os respectivos acessórios para bailes, concertos, espetáculos e festas campestres, e toda a sorte de divertimentos e jogos lícitos, exercícios saudáveis e de agilidade, como sejam equitação, ginástica, natação. ${ }^{44}$

De fato, o engenheiro chegou a atuar na reforma do Passeio Público e do Campo de Santana/Campo da Aclamação sem, contudo, chegar a construir uma instalação para a modalidade.

No decorrer do século, houve iniciativas semelhantes nas quais a modalidade esteve contemplada. Em 1885, por exemplo, anunciou-se pelos jornais a construção de um balneário às margens do canal do Mangue. Entre tantos intuitos, o responsável, Morris Kohn, pretendia construir tanques que serviriam para "exercícios de natação". ${ }^{45}$ Esse projeto se arrastou por anos, sendo ao final rejeitado pelo governo republicano. ${ }^{46}$

\footnotetext{
${ }^{40}$ Gazeta de Notícias, 29/06/1878, p. 4.

${ }^{41}$ Gazeta de Notícias, 31/07/1878, p. 4.

${ }^{42}$ Gazeta de Notícias, 02/08/1879, p. 4.

43 Gazeta de Notícias, 13/02/1881, p. 4.

${ }^{44}$ BRASIL. Decreto 1.867, de 17 de janeiro de 1857. Coleção de Leis do Império do Brasil - 1857, vol. 1 pt II, p. 12. (Publicação original). Disponível em: <http://www2.camara.leg.br/legin/fed/ decret/1824-1899/decreto-1867-17-janeiro-1857-557846-publicacaooriginal-78557-pe.html >. Acesso em: 19/09/2014.

45 Brazil, 31/03/1885, p. 1.

${ }^{46} \mathrm{O}$ ensino da natação também estava previsto em outro empreendimento, de uma companhia disposta a construir um balneário na ilha de Paquetá (O Paiz, 19/09/1890, p. 4).
} 
rev. hist. (São Paulo), n. 172, p. 299-334, jan.jun., 2015 http://dx.doi.org/10.11606/issn.2316-9141.rh.2015.98755
Victor Andrade de Melo

Enfrentando os desafios do mar: a nataç̃ó no Rio de Janeiro do século XIX (anos 1850-1890)

Hotéis também passaram a anunciar a oferta de instalações para a prática. Um dos primeiros estabelecimentos a fazer isso foi a citada chácara de Candido Antonio Pessoa de Amorim. Já chamado de Hotel Tijuca, paulatinamente deixou de se apresentar somente como um espaço para a recuperação da saúde para tentar atrair as famílias com fins de entretenimento e descanso. ${ }^{47}$

No mesmo bairro, Rosa Cândida Ferreira de Almeida gerenciava o Hotel do Comércio da Tijuca, dedicado prioritariamente ao "corpo comercial desta Corte". ${ }^{48}$ Entre as atrações oferecidas, em letras garrafais destacavam-se os banhos de natação. A referência aos comerciários merece registro. Estudos como o de Popinigis ${ }^{49}$ demonstram como esse grupo diverso e multifacetado ocupou espaço de importância na dinâmica social do Rio de Janeiro do século XIX.

Menos do que especificamente dedicados a turistas, que ainda não eram tão comuns na capital, esses estabelecimentos esperavam, por ocasião do verão, atrair uma faixa da população com mais posses, não só por causa do calor, bem como porque se situavam em locais mais distantes da região central, menos acometidos pelos problemas com as epidemias que grassavam na cidade.

O Hotel Ville Moreau, por exemplo, também localizado na Tijuca, claramente fazia menção à ocorrência. Tendo em vista a "estação calorosa", oferecia "os dormitórios mais arejados e sadios que se podem encontrar nos arrabaldes desta Corte", anunciando que possuía "um grande tanque de natação sem igual na América do Sul".50

Esses hotéis aproveitavam a farta disponibilidade de água desses arrabaldes. Os banheiros/tanques eram alimentados pelos rios. O bairro da Tijuca tornou-se atrativo até mesmo em função de certa valorização da natureza, primórdios de uma idealização de sua importância, processo que se deu em uma cidade que começava a sentir os efeitos do crescimento da estrutura urbana. ${ }^{51}$

De toda forma, houve também hospedarias dedicadas aos que vinham de fora nas quais a prática era mencionada. “Oferece-se aos Srs. viajantes

\footnotetext{
${ }^{47}$ Gazeta de Notícias, 16/01/1877, p. 4.

${ }^{48}$ O Globo, 13/01/1877, p. 4.

49 POPINIGIS, Fabiane. Proletários de casaca: trabalhadores do comércio carioca (1850-1911). Campinas: Editora da Unicamp, 2007.

${ }^{50}$ Gazeta de Notícias, 06/01/1883, p. 6.

51 Para mais informações sobre esse aspecto no cenário europeu, ver: PORTER, Roy. Os ingleses e o lazer. In: CORBIN, Alain (org.). História dos tempos livres. Lisboa: Teorema, 2001, p. 19-58; RAU$\mathrm{CH}$, André. As férias e a natureza revisitada. In: CORBIN, Alain (org.). História dos tempos livres. Lisboa: Teorema, 2001, p. 91-136. Sobre o caso do Rio de Janeiro, ver: DIAS, Cléber Augusto. Epopeia em dias de prazer: uma história do lazer na natureza (1779-1838). Goiânia: UFG, 2013.
} 
desta Corte cômodos e pensões em sobrado muito asseado, com banhos de chuva e natação, com latrinas inglesas, com boa vista para o parque, próximo à estação geral da estrada de ferro": 52 assim se anunciava um estabelecimento que, localizado nas redondezas do Campo de Santana, procurava se apresentar como limpo e higiênico, temas que se tornaram também valorizados em função da maior presença de estrangeiros e da dinamização do comércio.

Merece destaque o Hotel Jourdain, que chegou a publicar anúncios em três idiomas (português, inglês e francês) e se preocupou de forma ainda mais denotada em atrair também estrangeiros com a qualidade de seus serviços diferenciados, entre os quais "um grande banheiro para natação". ${ }^{53}$

Articulada com essa nova presença social da modalidade em distintas esferas, percebe-se a gestação de um mercado ao seu redor. Antonio David, que possuía um negócio ligado a produtos de cortiça, passou a oferecer "boias de salvação e natação". ${ }^{54}$ Da mesma forma, Guilherme Harvey anunciou "cintas de natação" em um "leilão de objetos de borracha". ${ }^{55} \mathrm{Na}$ La Ville de Paris, podia-se comprar "salva-vidas ou cintos de natação para aprender a nadar sem perigo de vida". ${ }^{56}$ Os mesmos artefatos se encontravam na renomada Perfumaria Ingleza de W. J. Louis. ${ }^{57}$

Esses produtos se relacionavam, como se pode ver, com as já citadas preocupações com a segurança. Pelos jornais, constantemente eram, aliás, noticiadas as invenções de aparelhos/implementos que preservavam o banhis$\mathrm{ta}^{58}{ }^{58}$ facilitavam o salvamento ${ }^{59}$ contribuíam para o aprendizado da natação. ${ }^{60}$

Com a gestação dessa dinâmica de consumo, não tardou para se veicular informações sobre uma moda para a natação, notadamente tendo em vista o público feminino. A princípio, tratava-se de uma vestimenta muito rigorosa. Para o memorialista Luiz Edmundo, assim se trajavam as mulheres para os banhos de mar em determinado momento:

\footnotetext{
${ }^{52}$ Gazeta de Notícias, 22/10/1882, p. 5.

53 Gazeta Nacional, 25/12/1887, p. 3.

${ }^{54}$ Correio da Tarde, 21/10/1858, p. 3.

55 Correio Mercantil, 21/07/1859, p. 3.

${ }^{56}$ Diário do Rio de Janeiro, 01/04/1860, p. 5.

57 A Nação, 14/08/1873, p. 4.

${ }^{58}$ Diário do Rio de Janeiro, 13/05/1857, p. 1; Diário do Rio de Janeiro, 28/02/1863, p. 1.

${ }^{59}$ Diário do Rio de Janeiro, 18/05/1875, p. 2; Gazeta de Notícias, 22/01/1876, p. 1.

${ }^{60}$ Correio Mercantil, 22/12/1857, p. 1. Para mais informações sobre a gestação de um mercado ao redor dos banhos de mar, ver BARICKMAN, B. J., op. cit.
} 
rev. hist. (São Paulo), n. 172, p. 299-334, jan.jun., 2015 http://dx.doi.org/10.11606/issn.2316-9141.rh.2015.98755
Victor Andrade de Melo

Enfrentando os desafios do mar: a nataç̃ó no Rio de Janeiro do século XIX (anos 1850-1890)

calças muito largas de baeta tão áspera que mesmo molhada não lhe pode cingir o corpo. Do mesmo tecido, um blusão com gola larguíssima, à marinheira, obrigada a laço, um laço amplo que serve de enfeite e, ao mesmo tempo, de tapume a uma possível manifestação de qualquer linha capaz de sugerir o feitio vago de um seio. As calças vão até tocar o tornozelo quando não caem num babado largo, cobrindo o peito do pé. Toda a roupa é sempre azul-marinho e encadarçada de branco. Sapatos de lona e corda, amarrados no pé e na perna, à romana. Na cabeça, vastas toucas de oleado, com franzido à Maria Antonieta, ou exagerados chapelões de aba larga, tornando disformes as cabeças, por uma época em que os cabelos são uma longa, escura e pesada massa. ${ }^{61}$

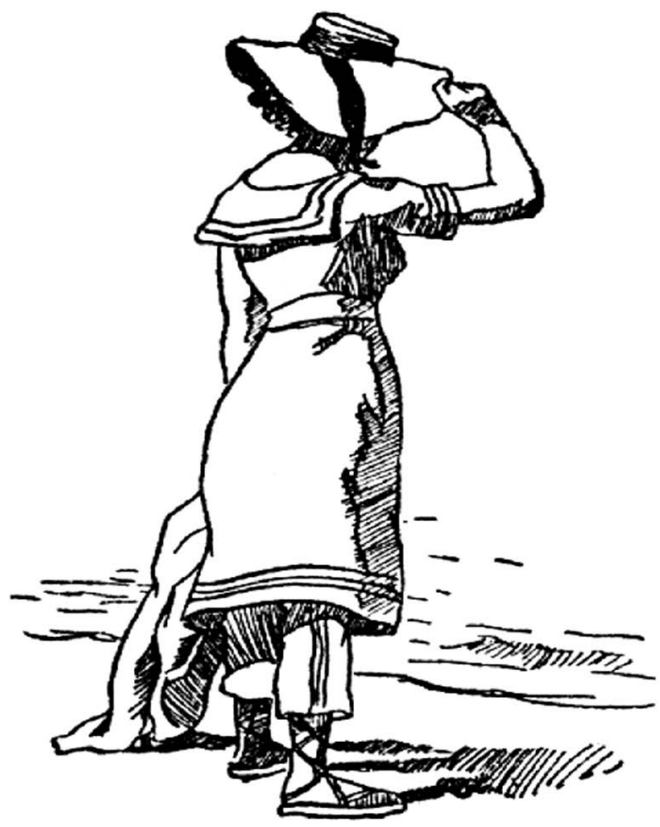

Roupa feminina para banhos de $\operatorname{mar}^{62}$

Como observam Fletcher $\mathcal{E}$ Kidder (op. cit.) sobre o hábito dos banhos nos anos 1850: "As senhoras se mostram elegantemente vestidas, com roupas feitas de um tecido escuro; mas não exibem o coquetismo das praias de banho francesas, em que as damas estudam a vestimenta que devem pôr no mar com o mesmo apuro que o fazem para um salão de baile" (p. 101). Nas

\footnotetext{
${ }^{61}$ EDMUNDO, Luiz. O Rio de Janeiro do meu tempo. $2^{\mathrm{a}}$ edição. Rio de Janeiro: Conquista, 1957, p. 838.

${ }^{62}$ EDMUNDO, Luiz, op. cit.
} 
duas últimas décadas do século, contudo, os jornais já veiculavam algumas mudanças. De fato, nos anos finais dos 1870, já há registros de mulheres nadando nas águas da cidade, na praia do Boqueirão do Passeio. ${ }^{63}$

Pelos números de $A$ Estação, periódico que tinha a moda como assunto principal, ${ }^{64}$ podemos acompanhar as sugestões de vestimentas para as mulheres que procuravam os banhos de mar e a natação. Em 1879, apresentou-se o seguinte modelo: "A blusa e a calça são abotoadas, uma à outra, no cinto sofrivelmente largo, pregado de modo a correr com facilidade. Este modelo, de baetilha branca, é apertado por uma faixa, e enfeitado de bordado a ponto de marca". ${ }^{55}$

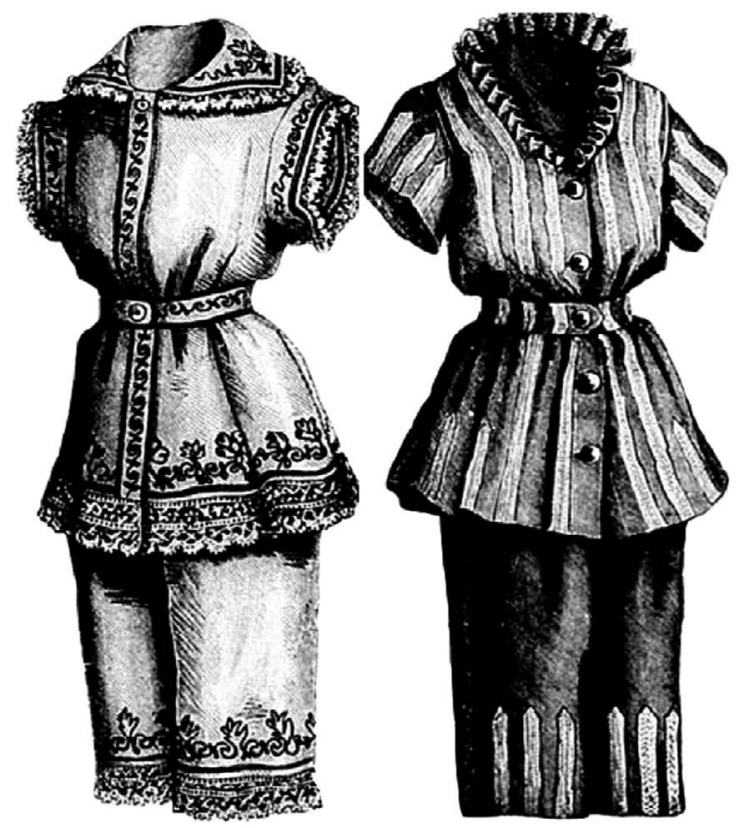

Roupas femininas de banhos de mar ${ }^{66}$

Quase um ano depois, o tema retorna na capa de uma edição do mesmo periódico. Na coluna "Crônica da Moda", da lavra de Antonina Aubé que es-

\footnotetext{
${ }^{63}$ Gazeta de Notícias, 19/04/1877, p. 2.

${ }^{64}$ Para mais informações sobre o periódico, ver: CRESTANI, Luís. O perfil editorial da revista $A$ Estação: Jornal ilustrado para a família. Revista Anpoll, v. 1, n. 25, 2008, p. 325-353.

${ }^{65}$ A Estação, 17/07/1879, p. 118.

${ }^{66}$ A Estação, 17/07/1879, p. 118.
} 
crevia direto de Paris, observa-se a possibilidade de uso de uma vestimenta menos rigorosa para as que praticavam a modalidade: "As senhoras que aprenderem a nadar ou conhecerem a natação, a farão mais curta e com mais roda, para que não pareça repuxada, o que é extremamente feio e incômodo". ${ }^{67}$ A longa matéria descreve todos os detalhes da vestimenta, ainda bastante rigorosa se compararmos aos parâmetros atuais. Todavia, há que se destacar que a abordagem enfatiza mais a elegância e o conforto do que o pudor, embora essa seja uma dimensão que não deve ser negligenciada. Essa mudança pode ser sutilmente observada na "maior ousadia" de um modelo publicado no periódico numa edição de 1881:68

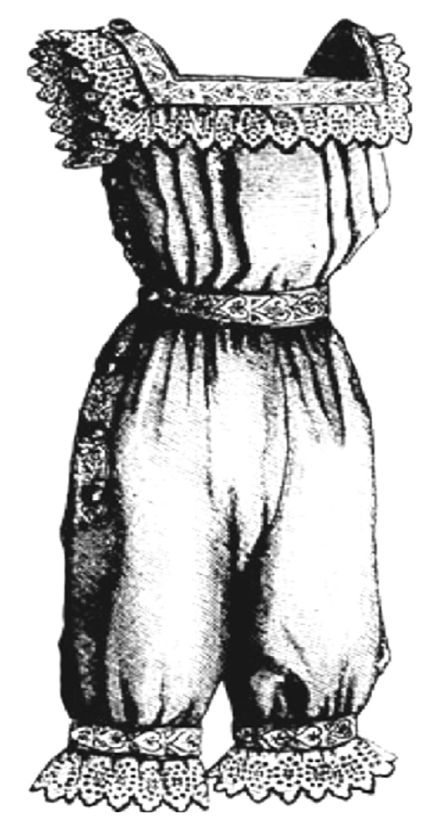

Roupa feminina de banhos de $\operatorname{mar}^{69}$

Havia uma conexão com o que ocorria no cenário europeu, uma tendência forte no Rio de Janeiro da ocasião. No decorrer do século, sempre às vésperas da estação mais quente, o tema voltava à baila na revista, com

\footnotetext{
${ }^{67}$ A Estação, 15/07/1880, p. 1.

68 A Estação, 15/07/1881, p. 154.

${ }^{69}$ A Estação, 15/07/1881, p. 154.
} 
abordagem semelhante. Além das vestimentas, comentavam-se os comportamentos e cuidados com a saúde e a beleza a serem observados. Sempre se faziam ressalvas às distensões aceitáveis para as "nadadoras", de maneira a não prejudicar a performance.

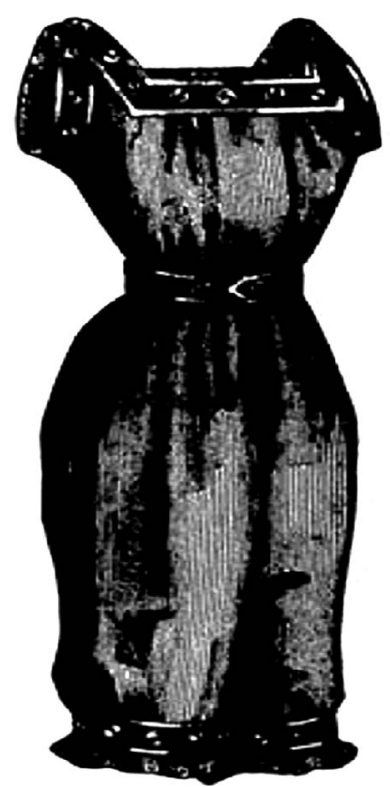

Costume para nadadoras ${ }^{70}$

Já mais para o fim do século, a colunista Paula Cândida, na seção de capa do Correio da Moda, é ainda mais enfática no que tange à participação feminina. Ao observar que as mulheres já tomam parte ativa em diversões públicas ("As senhoras idosas ficam admiradas diante dos jogos aos quais tomam parte as suas descendentes"), entre as quais duas novidades, o tênis e o ciclismo (esse último rechaçado pela cronista por ser deselegante e sem função), a autora sugere que nadar seria um dos mais graciosos gêneros de divertimento. Mais ainda, para ela, “a natação é indispensável para todas as senhoras e devia fazer parte da educação". ${ }^{11}$

\footnotetext{
${ }^{70}$ A Estação, 15/07/1886, p. 145.

${ }^{71}$ A Estação, 31/07/1892, p. 1. Para mais informações sobre a moda feminina para banhos de mar, ver BARICKMAN, B. J., op. cit.
} 


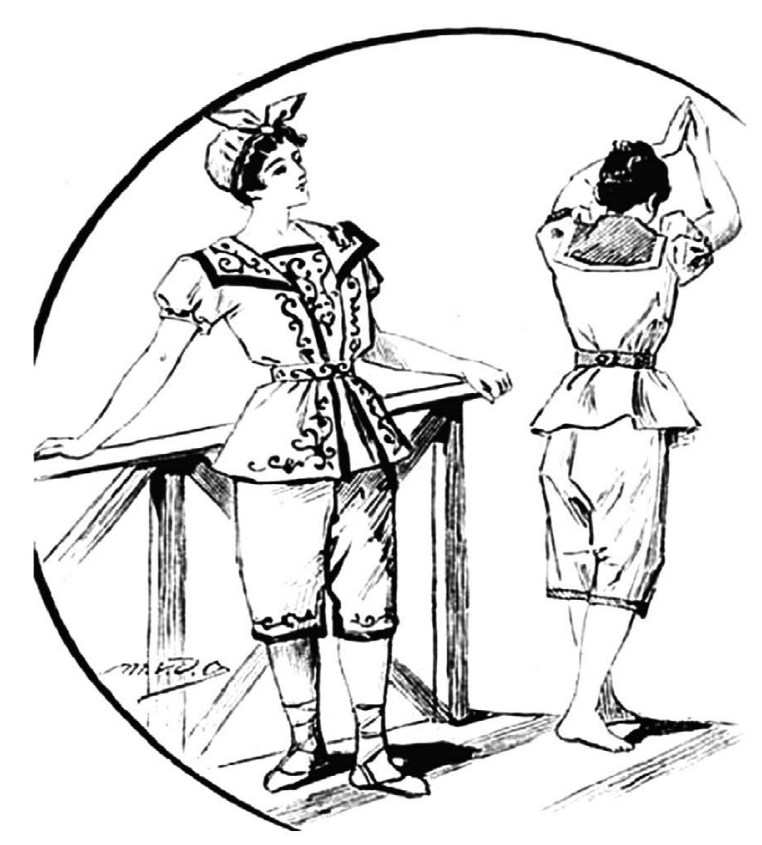

Roupas femininas de natação ${ }^{72}$

\section{A consolidação de um costume}

A natação se tornou um assunto da pauta feminina, mais um indicador de sua difusão na sociedade fluminense. Mesmo que enfrentasse resistências, vários aspectos contribuíram para uma maior aceitabilidade da ideia de que mulheres podiam praticar a modalidade. Um deles foi a circulação de notícias de nadadoras que se destacavam por proezas realizadas no exterior, notadamente as façanhas de miss Agnes Beckwith, chamada de "a primeira nadadora do mundo".73

Outro importante estímulo foi o posicionamento favorável de alguns cronistas, médicos e pedagogos. Mesmo o colunista de um jornal como $O$ Apóstolo, que tinha olhares mais conservadores em função de sua vinculação religiosa, proclamava que a modalidade seria para as moças "o mais simples

\footnotetext{
${ }_{72}$ A Estação, 31/08/1897, p. 128.

73 O Apóstolo, 13/09/1882, p. 3; Mercantil, 30/08/1876, p. 3; O Apóstolo, 04/07/1880, p. 2. Sobre a nadadora, ver: DAY, Dave. "What girl will now remain ignorant of swimming?" Agnes Beckwith, aquatic entertainer and Victorian role model. Women's History Review, v. 21, n. 3, 2012, p. 419-443.
} 
rev. hist. (São Paulo), n. 172, p. 299-334, jan.-jun., 2015 http://dx.doi.org/10.11606/issn.2316-9141.rh.2015.98755
Victor Andrade de Melo

Enfrentando os desafios do mar: a natação no Rio de Janeiro do século XIX (anos 1850-1890)

e modesto exercício para o desenvolvimento físico". ${ }^{74}$ Felix Ferreira, tratando do tema da educação feminina, em A Mãe de Família, ${ }^{75}$ sugere que a natação poderia ser boa estratégia para combater a inatividade, fundamental para o bom desenvolvimento das mais jovens. ${ }^{76}$

Antes deles, de forma pioneira, no Jornal das Senhoras, periódico eminentemente dedicado ao público feminino, a redatora Gervásia Neves, ${ }^{77}$ ao indicar e elogiar os banhos, ressalvando que "as ideias que vou exprimir não são propriamente minhas, mas sim lidas em escritos de pessoas habilitadas para falar da higiene e da propreté", aconselha às mulheres que visitem "a barca de natação, há tão pouco tempo construída", ${ }^{78}$ entre outros locais da cidade nos quais poderiam se banhar no mar (como a ilha da Pombeba, a ponta do Caju, a praia do Flamengo). ${ }^{79}$

Em 1885, um cronista chegou a afirmar que não mais se justificavam as suspeitas e restrições que ainda pendiam no que tange ao envolvimento de "donzelas" com as atividades físicas. Para ele, a questão era saber como bem escolhê-las, sua pertinência e os limites a serem observados. Nesse sentido, a natação seria "um excelente exercício higiênico que as meninas podem facilmente por em prática e que em todos os colégios dever-lhes-iam ser ensinado sistematicamente". ${ }^{80}$

Como se pode ver, houve algumas preocupações com o ensino da natação. De fato, muitas foram as iniciativas nesse sentido, entabuladas em espaços não escolares (barcas de banhos, casas de banhos, clubes) e escolares (instituições militares, civis públicas e notadamente civis privadas). Essas ações também se relacionavam ao fato de que crescentemente valorizavamse os exercícios físicos, reconhecia-se a importância da ginástica. A despeito

\footnotetext{
${ }^{74}$ O Apóstolo, 06/02/1878, p. 2.

75 Para um perfil desse importante periódico, ver: CARULA, Karoline. Carlos Costa e A Mãe de Familia: concepções acerca da maternidade em fins dos oitocentos. In: FERREIRA, Tânia Maria Tavares Bessone da Cruz; NEVES, Lucia Maria Bastos Pereira das; GUIMARÃES, Lucia Maria Paschoal (org.). Elites, fronteiras e cultura do Império do Brasil. Rio de Janeiro: Contra Capa, 2013, p. 203-228.

76 A Mãe de Família, outubro 1880, p. 151.

77 Para mais informações sobre o periódico e a redatora, ver: LIMA, Joelma Varão. Jornal das Senhoras: as mulheres e a urbanização na Corte. Cadernos Ceru, São Paulo, v. 21, n. 2, 2010, p. 227-240.

${ }^{78}$ As barcas de banho, instaladas dentro do mar, na região do cais Pharoux, centro da cidade, permitiam aos interessados banhar-se sem se expor nas praias. Existiam no Rio de Janeiro desde os anos 1810. A partir da década de 1850, passaram a também oferecer tanques para a natação.

79 Jornal das Senhoras, 05/02/1854, p. 6.

${ }^{80}$ A Mãe de Família, 15/05/1885, p. 69.
} 
da relevância do assunto, mais um indicador da vulgarização da modalidade, por limite de espaço, não nos aprofundaremos nesse debate.

Por vias diversas, portanto, as mulheres, assim como os homens, tomaram parte em iniciativas ligadas à natação. As restrições ainda permaneceriam por muitos anos, ${ }^{81}$ mas naquelas décadas finais já havia algumas nadadoras habitueés. Essa maior presença feminina nas praias despertava novas emoções: "alta, esbelta, eu esperava sempre para vê-la sair da sua cabina, e admirar o belo manto de ouro que lhe faziam os seus magníficos cabelos que ondeando lhe caíam até os pés". ${ }^{22}$ Mesmo que com limites, gestava-se uma nova excitabilidade. O pudor era um dos aspectos que mais preocupava a muitos, em função das vestimentas menos rigorosas e do encontro entre indivíduos de ambos os sexos.

Pelos jornais, é possível encontrar várias preocupações com a moralidade pública, muitas denúncias de que os banhistas "se apresentam em trajes impróprios e indecentes, ofendendo assim o pudor das famílias, a moral e os bons costumes". ${ }^{83}$ Em 1882, um leitor que assina como Faiplay chegou a defender os frequentadores da praia, lembrando a necessidade de avançar os costumes e a utilidade da natação para a saúde. ${ }^{84}$ De toda forma, durante muito tempo persistiram as reclamações: "Para variar a natação está em voga e continuam alguns banhistas, nas nossas praias, a apresentarem-se em toilletes do gênero collant, e em cores carnavalescas. A polícia, cheia de pudor, finge não dar por isso". ${ }^{85}$

Em abril de 1896, contando com grande público, estreia no Recreio Dramático uma peça de Moreira Sampaio que ironizava os novos hábitos, o Rio-Nu. Protagonizava-a o célebre Brandão, o "popularíssimo", e Pepa Ruiz, notória atriz. O espetáculo logrou grande sucesso com sua trama cômica: ao ver a situação do Rio de Janeiro, o diabo manda seu filho para tomar conta do que é quase um inferno. Este, por sua vez, acaba adorando a cidade. Dizia-se em certa parte:

\footnotetext{
${ }^{81}$ Ecila Worms, colunista de moda de $O$ Paiz, já no final do século observou: "lamento que não sejamos todas nós ótimas nadadoras (...): seriamos mais fortes, mais ágeis, mais intrépidas" $(O$ Paiz, 27/12/1897, p. 1).

${ }^{82}$ Brazil, 28/05/1885, p. 1.

${ }^{83}$ O Cruzeiro, 01/12/1882, p. 3.

${ }^{84}$ O Globo, $15 / 12 / 1882$, p. 4.

${ }^{85}$ Gazeta da Tarde, 06/03/1884, p. 3.
} 
Victor Andrade de Melo

Enfrentando os desafios do mar: a natação no Rio de Janeiro do século XIX (anos 1850-1890)

Os rapazes elegantes

Lá da Rua do Ouvidor

E as raparigas galantes

Que só vivem para o amor

Para o calor mitigar

Nesta calmosa estação

Nunca deixam de tomar

Os banhos do Boqueirão.

Em função dessas preocupações, foi de grande importância a instalação de casas de banhos no litoral. Funcionavam como vestiários que permitiam a troca e a guarda das roupas, eximindo os banhistas e nadadores de andarem pelas ruas com os "escandalosos" trajes apropriados para o mar. Além disso, era também oferecida alguma estrutura de segurança para os frequentadores.

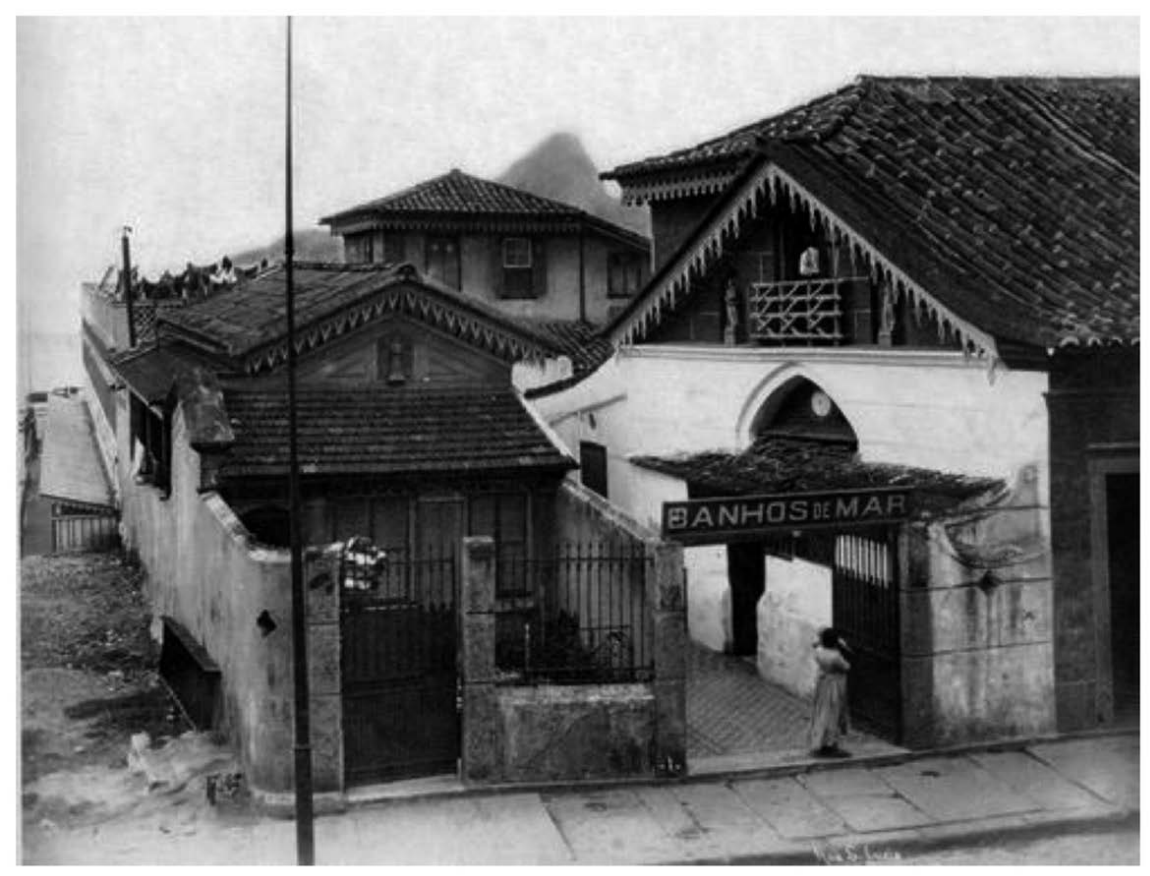

Casa de Banho na rua Santa Luzia. Na parte de trás, se encontra o mar (pode-se ver na imagem a ponta do Pão de Açúcar). Década de 1910. Foto de Augusto Malta (Acervo George Ermakoff).

A empresa Banhos Populares Fluminenses assim anunciava seus serviços: "barracas asseadas e confortáveis, pontes para banhos de choque e banheiros-nadadores para acompanharem as senhoras ao mar e socorrerem 
a qualquer sinistro". 86 De fato, ao final do século, quando o Conselho Municipal estabeleceu um regulamento para todos os tipos de casas de banho, esse tipo de oferta tornou-se obrigatória. ${ }^{87}$

As casas de banhos muito ajudaram na consolidação do hábito da natação, inclusive no que tange à possibilidade de adoção de um novo modelo de corpo. Paulatinamente, os homens passariam a "arriscar" a exibir seus músculos pela cidade, supostos sinais de saúde e disposição.

Nos últimos anos do século XIX, Ignotus, provavelmente o jornalista e literato Joaquim Serra, ao escrever sobre a praia do Boqueirão do Passeio, sugeriu que se deveria dedicar mais atenção à natação exatamente porque "desempena-lhes a estatura e enrijece-lhes os músculos, dando-lhe essa atitude de altivez de quem ama o perigo, porque se sente nele à vontade como em seu elemento natural". ${ }^{88}$

Além dos competidores, assunto que abordaremos no próximo item, a cidade logo passaria a conviver com personagens como Neville, que "não podia passar bem o dia quando não tivesse uma hora ou duas gracejado na água do Boqueirão. (...) Devia à natação o belo desenvolvimento dos seus músculos e ao convívio do mar, a horas matinais, a sua serena alegria de todos os instantes". ${ }^{89}$

O desenvolvimento da prática da natação acabou tirando proveito da conformação e popularização do remo, com ele compartilhando o estímulo da dinâmica da atividade (era importante para os remadores aprenderem a nadar), o modo de funcionamento (especialmente o modelo de organização de competições) e muitos símbolos (ligados às noções de progresso e modernidade). ${ }^{90}$

No que tange à difusão de um novo modelo de corpo, vejamos a diferença registrada por dois literatos. Ao comentar regatas realizadas em 1888, sugeriu Raul Pompeia:

${ }^{86}$ Diário do Rio de Janeiro, 16/11/1873, p. 4. Para uma melhor compreensão sobre a atuação dos banheiros-nadadores, funcionários que auxiliavam os clientes na sua ida ao mar, ver BARICKMAN, B. J., op. cit.

${ }^{87}$ Cidade do Rio, 22/10/1896, p. 2.

${ }^{88}$ O Paiz, 11/03/1891, p. 1.

${ }^{89}$ Cidade do Rio, 06/11/1889, p. 1.

${ }^{90}$ Para mais informações, ver: MELO, Victor Andrade de. O corpo esportivo nas searas tupiniquins: um panorama histórico. In: AMANTINO, Marcia E PRIORE, Mary Del. (org.). História do corpo no Brasil, v. 1. São Paulo: Editora da Unesp, 2011, p. 123-145. 
Os corredores apresentam-se com o vestuário próprio, de meia justa ao corpo.

Mais do que o aproveitamento dos exercícios de carreira, devia interessar ao observador a desagradável exibição de formas sem elegância e sem músculo que a roupa de meia proporcionava. Bem pobre plástica a da nossa mocidade para um espetáculo de ginásios. Corpore sano!... meus amigos. ${ }^{11}$

Já João do Rio, em crônica publicada em 1917, mas se referindo aos anos finais do século XIX, registrou com empolgação: "Rapazes discutiam muque em toda parte. Pela cidade, jovens, outrora raquíticos e balofos, ostentavam largos peitorais e a musculatura herculeana dos braços. Era o delírio do rowing, era a paixão dos esportes".

Tendo em vista esse quadro, não surpreende o desenvolvimento de uma natação competitiva, a organização de provas com distintos formatos, processo que se tornou mais claro nos anos finais do século XIX. Discutamos o delineamento dessa faceta da modalidade no Rio de Janeiro.

\section{Competindo nas águas}

A organização de competições de natação tem relação com o conjunto de dimensões que cercava a vulgarização da prática na cidade: preocupações com a saúde, mais frequente uso do mar para banhos, inquietações com a segurança dos banhistas, maior aceitação de exibição corporal e de uma nova compleição muscular, delineamento de uma dinâmica pública mais intensa (inclusive em função da gestação de um mercado de entretenimento), valorização dos exercícios físicos nas escolas ena sociedade como um todo. O diferencial é que o caráter de disputa de alguma forma potencializava esses aspectos.

Não surpreende que tenha obtido repercussão pública a realização de uma série de "desafios aquáticos". As primeiras dessas situações divulgadas pelos jornais diziam respeito a fatos do exterior, feitos de alguns personagens de renome internacional, reconhecidos por sua postura audaz em rios e mares.

Foi, por exemplo, comum a exaltação das proezas do inglês Matthew Webb, pioneiro a cruzar nadando o canal da Mancha, costumeiro superador de recordes e vencedor de apostas: "O maravilhoso nadador é lento, tem movimentos doces e vigorosíssima seção de pernas. Conserva a cabeça baixa, tanto que a cada movimento de braços a água excede ao nível da boca".92

\footnotetext{
${ }^{91}$ POMPEIA, Raul. Crônicas do Rio. Rio de Janeiro: Secretaria Municipal de Cultura, 1996, p. 65.

${ }^{92}$ Gazeta de Notícias, 23/08/1875, p. 2.
} 
Também foi muito incensado pelos jornais o norte-americano Paul Boyton, descrito como aventureiro destemido, dono de um caráter indomável.93

Logo foram realizados desafios em águas fluminenses. Em 1881, um relojoeiro alemão estabelecido no Brasil, Theodor John, ${ }^{94}$ disputou uma prova com o comerciante Joaquim Antonio de Souza; o percurso estipulado foi da ponta da Armação, em Niterói, ao morro da Viúva, na região de Botafogo, Rio de Janeiro. ${ }^{55} \mathrm{Na}$ verdade, o brasileiro já vinha protagonizando aventuras aquáticas, tornando-se conhecido na Corte, saudado como "primeiro nadador do Brasil", ${ }^{96}$ sendo inclusive premiado por suas façanhas. ${ }^{97}$

Os nadadores levaram em torno de duas horas e 30 minutos para percorrer as cerca de seis milhas, chegando à costa saudados por "um grande número de pessoas postadas nas margens".98 Barcos foram ao encontro dos aventureiros para celebrar a proeza. Nessa primeira contenda, sagrou-se vitorioso o brasileiro. Todavia, o alemão contestou o resultado, desmereceu o concorrente, alimentou a rivalidade e lançou as bases de novos desafios. ${ }^{99}$

Pelos jornais, pode se ver o anúncio de muitas disputas, em diferentes trajetos, cada vez mais distantes, ousados e perigosos. ${ }^{100}$ Bastava alguém avisar que faria "um passeio" por um percurso e logo surgiam interessados em participar da contenda. A cidade acompanhava tudo com curiosidade. O público comparecia em peso às praias para assistir in loco às "lutas aquáticas". ${ }^{101}$

Eram ocasiões narradas como grandes aventuras, destacando-se os riscos enfrentados: as condições da maré, o encontro com peixes e outros animais marinhos (era comum que golfinhos pulassem pelo caminho), o frio (combatido com paradas para ingerir alguma bebida alcoólica). Mais ainda, havia o receio de que os competidores não aguentassem o esforço intenso. Por isso, os acompanhavam botes com remadores prontos a ajudá-los, caso fosse necessário.

Esses desafios ajudaram a criar uma melhor ambiência para as competições. Como sugeriu um leitor: “Essas travessias não deixam de trazer grande

\footnotetext{
93 Ver, por exemplo, Diário do Rio de Janeiro, 07/03/1877, p. 3.

${ }^{94}$ Era proprietário, junto com E. M. Saucken-John, de uma relojoaria e ourivesaria na rua Visconde Uruguai, em Niterói.

${ }^{95}$ Gazeta de Notícias, 28/01/1881, p. 2.

${ }^{96}$ Gazeta da Tarde, 09/03/1881, p. 2.

${ }^{97}$ Novo e completo índice cronológico da história do Brasil, 1879, op. cit., p. 88.

${ }^{98}$ Gazeta de Notícias, 28/01/1881, p. 2.

${ }^{99}$ Gazeta de Notícias, 13/02/1881, p. 2; Gazeta da Tarde, 16/02/1881, p. 1.

${ }^{100}$ Ver, por exemplo, Gazeta de Notícias, 11/03/1881, p. 3.

${ }^{101}$ Ver, por exemplo, Gazeta da Tarde, 09/03/1881, p. 2.
} 
proveito à mocidade porque eles provocam o amor pela natação, que é, sem contestação, de grande utilidade". ${ }^{102}$ Logo, as disputas passaram a também ser mais frequentemente realizadas próximo das praias. As "corridas marítimas" tornaram-se mais uma atração para os que desfrutavam os prazeres do mar.

A atenção crescia quando havia o que na época era considerado uma grande ousadia: "a protagonista era uma elegante moça de 20 anos, que saiu vitoriosa do torneio, realizando com admirável coragem a travessia da praia do Boqueirão a Villegagnon, e a do regresso para o ponto de partida". Vários nadadores dela se aproximaram, julgando-a cansada, se surpreendendo com a coragem e obstinação da jovem. O jornal não deixou de registrar a relevância do feito para o sexo feminino, divulgando o nome da heroína: "Adélia Cardoso da Silva, pertencente a uma das mais distintas famílias da nossa cidade". ${ }^{103}$

Os desafios seguiram sendo realizados pari passu com a organização das "regatas de nadadores" promovidas por agremiações. A pioneira especificamente dedicada à modalidade parece ter sido fundada em 1867, a Associação Humanitária de Natação, cujo intuito era "instruir os sócios na arte da natação, estabelecer corridas públicas, honrar com uma medalha qualquer sócio e gratificar com um prêmio pecuniário qualquer estranho que, na baía do Rio de Janeiro, salvar de afogar-se algum seu semelhante". ${ }^{104}$

Formada por empregados do comércio, liderados por José da Silva Ethena (importante negociante de origem portuguesa), Elkim Hime Junior (conhecido contador, cuja família futuramente estaria envolvida com a criação do Botafogo Futebol Clube) e o engenheiro Antonio Marques Paixão, a fundação da agremiação foi muito saudada pelos jornais, notadamente por seus fins humanitários. ${ }^{105}$

Não conseguimos mais informações sobre essa iniciativa. De toda forma, vale registrar que argumentos semelhantes seriam usados pelos futuros clubes de natação, uma tendência comum nas iniciativas esportivas em geral: utile dulce - sugeria-se que não se tratava de qualquer divertimento, mas sim de uma diversão que deveria ter uma utilidade social.106

\footnotetext{
${ }^{102}$ Gazeta de Notícias, 15/03/1881, p. 3.

${ }^{103} \mathrm{O}$ Globo, 13/02/1882, p. 2.

${ }^{104}$ Novo e completo índice cronológico da história do Brasil, 1867, op. cit., p. 121.

${ }^{105}$ Correio Mercantil, 6 jul 1867, p. 2.; Diário do Rio de Janeiro, 06/07/1867, p. 1 e 2.

${ }^{106}$ Para mais informações sobre essa dimensão no desenvolvimento do fenômeno esportivo no Rio de Janeiro, ver: MELO, Victor Andrade de. "Temos apaixonados para o mar e para a terra": representações do esporte nos folhetins (Rio de Janeiro; 1851-1855). Revista Brasileira de Educação Física e Esporte, São Paulo, v. 27, n. 4, 2013, p. 553-566.
} 
Foi mesmo numa competição promovida em março de 1876 por uma das mais importantes agremiações de remo do Rio de Janeiro, o Clube de Regatas Guanabarense, que pela primeira vez foi prevista a organização institucional de páreos de nadadores. ${ }^{107}$ Deve-se ter em conta que essa associação tinha alguma afinidade com a modalidade, tendo mesmo previsto nos seus estatutos, no parágrafo $2^{\circ}$ do capítulo I ("Da Sociedade e seus fins"), o estabelecimento de uma escola de natação. ${ }^{108}$

No ano seguinte, pelos jornais se anunciou a realização, na praia de Botafogo, de uma nova regata de nadadores, "um gênero de divertimento muito usado e apreciado em alguns lugares na Europa, e que provavelmente se aclimatará aqui", ${ }^{109}$ conforme perspectiva um cronista. Tratava-se de iniciativa do já citado Joseph Fogliani, que, como vimos, recebera autorização para criar uma escola de natação na região da Tijuca.

O estabelecimento nunca chegou a sair do papel, mas, aproveitando a ocasião, o empresário lançou a ideia de criação do Club Boyton, destinado aos interessados na natação. Pelos jornais, foi anunciada até mesmo a diretoria da agremiação, integrada por alguns personagens importantes do Império, como o marquês de Herval, o barão da Penha e os conselheiros Pinto Lima e Saldanha Marinho. ${ }^{110}$

O evento, primeiro exclusivamente dedicado à natação, realizado em 6 de maio de 1877, contou com 20 nadadores inscritos para cinco páreos de 500 metros (cada um com cinco competidores, o último somente com os vencedores dos outros quatro). ${ }^{111}$ Para o público interessado, além do litoral, havia disponível uma arquibancada (com ingressos pagos).

As provas não chegaram a empolgar, nem a atrair grande assistência. Na coluna "Conversemos", no folhetim da Gazeta de Notícias, um cronista dá conta do desânimo que marcou o evento: “Quanto à regata de nadadores, (...), o Club Boyton lucrou apenas um magnífico e longo banho. (...). Pouca gente, e

\footnotetext{
$\overline{{ }^{107} \text { Gazeta de Notícias, } 24 / 03 / 1876, \text { p. } 2 .}$

${ }^{108}$ Decreto $\mathrm{n}^{\mathrm{0}}$ 7.122, de 28 de dezembro de 1878. Aprova os estatutos do Club de Regatas Guanabarense. Coleção de Leis do Império do Brasil - 1878, vol. 1, p. 904 (publicação original). Disponível em: <http://www2.camara.leg.br/legin/fed/decret/1824-1899/decreto-7122-28dezembro-1878-548250-publicacaooriginal-63270-pe.html >. Acesso em: 26/09/2014.

${ }^{109}$ Gazeta de Notícias, 08/04/1877, p. 1.

${ }^{110}$ Gazeta de Notícias, 03/05/1877, p. 1.

111 Gazeta de Notícias, 26/04/1877, p. 2; Gazeta de Notícias, 07/05/1877, p. 2.
} 
esse pouco distraído e indiferente. Despretensão nas toilletes e abandono nos ademanes $(. . .)^{\prime \prime} .12$

O clube não teve vida longa. A despeito disso, vários desafios surgiram da iniciativa, alguns até mesmo com certa organização, com divisão de páreos e estrutura para acolher o público. ${ }^{113}$ Durante muitos anos, não passaram de ocasionais essas iniciativas de promoção de páreos de natação.

Em 1878, por exemplo, o Clubede Regatas Guanabarense uma vezmais promoveu uma prova da modalidade em uma regata de remo. Tratou-se, na verdade, de uma ocasião promocional. Disputaram a contenda dois envolvidos com o espetáculo teatral já citado, Francisco Tilly e o "homem-peixe" mr. Watson. ${ }^{114}$

Provas da modalidade também integraram festividades diversas, como a regata promovida na enseada de Botafogo, em março de 1884, pela Sociedade Abolicionista Cearense, com o intuito de comemorar a libertação dos escravos na província do Ceará, ocasião que contou com enorme público. Houve um páreo de natação, de 200 metros, disputado por cinco alunos da Escola Militar. ${ }^{115}$

Quem também promoveu "corridas de natação" foi uma das principais casas de banhos da cidade, a High-Life (localizada na praia do Flamengo), no âmbito das comemorações de seu $1^{\circ}$ aniversário, em 1886. ${ }^{116}$ Dos cinco páreos, os dois previstos para nadadoras não se realizaram pelas condições de tempo e do mar. ${ }^{117}$ Nesse caso, a iniciativa se articulava com as atividades da escola de natação que no estabelecimento havia, sendo digna de registro a previsão de participação feminina. A propósito, nesse mesmo ano, Ignez Victoria de S. e Souza tornou-se a primeira mulher a vencer uma prova de natação, numa das competições promovidas pelo Grêmio Filhos de Tétis, no Boqueirão do Passeio, eventos que sempre contavam com grande público. ${ }^{118}$

Nessa mesma época, tornaram a surgir agremiações que dedicavam maior atenção à modalidade. Em 1884, foi fundado o Clube de Natação Niteroiense, ${ }^{119}$ na cidade que acolheria o Clube de Exercícios Náuticos, criado em 1895, em Icaraí, por cidadãos ilustres de Niterói. ${ }^{120}$

\footnotetext{
112 Gazeta de Notícias, 09/05/1877, p. 1.

113 Ver, por exemplo, Gazeta de Notícias, 19/06/1877, p. 1.

${ }^{114}$ Gazeta de Notícias, 15/09/1878, p. 2.

${ }^{115}$ A Folha Nova, 30/03/1884, p. 4.

${ }^{116}$ Diário de Notícias, 05/01/1886, p. 4.

${ }^{117}$ Diário de Notícias, 07/01/1886, p. 1.

${ }^{118}$ Diário de Notícias, 18/01/1886, p. 1.

${ }^{119}$ A Folha Nova, 24/04/1884, p. 2.

${ }^{120}$ Gazeta da Tarde, 03/03/1895, p. 2.
} 
Essa agremiação, depois renomeada para Clube de Regatas Icaraí, merece destaque pela forma como seus atletas eram apresentados, como "moços fortes e robustos, reçumando vida, reçumando saúde e alegria". ${ }^{121}$ Eram reconhecidos pelos "músculos retesos (...), o pescoço cheio, robusto, os braços valentes, vangloriando-se da força". Ao celebrar as iniciativas da associação, o cronista que assina como Lorgnon exaltou: "Essa geração de tísicos, escrofulosos, anêmicos, podres, a que pertencemos, vai enfraquecendo dia a dia, cada vez mais. Combatamos a degenerescência!".

No Rio de Janeiro, em 1886, anunciou-se o evento inaugural do Clube Fluminense de Regatas e Natação, a ser realizado na praia das Palmeiras, na região de São Cristóvão. Foram cinco páreos de remo e cinco de natação, dos quais um para mulheres. ${ }^{122}$ Alguns anos depois, em 1892, na ponta do Caju criou-se o Clube de Regatas Fluminense, com o intuito de desenvolver "o gosto pelas regatas e exercícios da natação". ${ }^{123}$

\section{Clube de Natação e Regatas: um ponto de inflexão}

Em 1896, foi criada uma agremiação que desempenhou um importante papel na difusão da natação competitiva na cidade, o Clube de Natação. Como os sócios, boa parte gente ligada ao comércio, ${ }^{124}$ eram habituées das praias e reconhecidos por ajudarem no salvamento de vítimas de afogamentos, em muitas ocasiões pelos jornais saudou-se a iniciativa por aliar a diversão com preocupações humanitárias: "quem se der ao prazer de madrugar e dirigir-se ao Boqueirão do Passeio, com certeza não deixará de repetir diariamente esse prazer (...). Ainda o dia está lá (...) e já os rapazes do Club de Natação exercitam-se para o grande concurso de natação".125

O Clube de Natação se localizava numa região da cidade, nas praias do Centro, onde, na transição dos séculos XIX e XX, se sediavam muitas agremiações, com destaque para o Clube de Regatas Boqueirão do Passeio (fundado em 1897). Próximo, na travessa do Maia, na praia de Santa Luzia, instalar-se-iam o Clube de Regatas Vasco da Gama (1898) e o Clube Interna-

\footnotetext{
${ }^{121}$ Diário de Notícias, 09/03/1895, p. 2.

${ }^{122}$ Diário de Notícias, 12/12/1886, p. 4.

${ }^{123}$ Diário de Notícias, 13/12/1892, p. 1.

${ }^{124} \mathrm{O}$ Paiz, 03/12/1896, p. 3.

${ }^{125} \mathrm{O}$ Paiz, 11/12/1896, p. 3
} 
cional de Regatas (1900). Nas redondezas, o Clube de Regatas do Flamengo (1895) tinha sede na praia de mesmo nome.

Desde a atividade inaugural, realizada em dezembro de 1896, os eventos do Clube de Natação foram marcados pela boa organização e pelo cuidado em bem receber o público, a imprensa e os sócios das agremiações que tomaram parte nas provas. A estrutura das competições muito se parecia com as do remo, inclusive no tocante às festividades: bandas de música, recepções com brindes e acepipes, bailes. ${ }^{126}$

O público comparecia em peso: "O terraço do Passeio Público e as imediações das praias achavam-se apinhados de muitas famílias e curiosos".127 Além disso, muitos assistiam às provas em embarcações. $\mathrm{O}$ cronista de $O$ Paiz não teve dúvidas de afirmar com empolgação: "está iniciado um gênero de sport higiênico, salutar e sobretudo utilíssimo". ${ }^{128} \mathrm{O}$ "intrépido clube de netuno", como em algumas ocasiões foi chamado o Natação, logo foi aceito entre os mais fashionables da cidade, sendo seus membros reconhecidos pelo ar saudável e pelos músculos pronunciados.

Logo na segunda atividade, prevista para janeiro de 1897, o clube anunciou o desejo de realizar um páreo de remo. Tratava-se de uma inversão: se era comum a inserção de provas de natação nas corridas de botes, agora a modalidade era a estrela principal. As agremiações náuticas, todavia, não demonstraram entusiasmo pela ideia e o evento acabou se realizando somente com os nadadores. ${ }^{129}$

Isso de forma alguma diminuiu o sucesso da iniciativa e o acolhimento do público: "Ainda não eram 6 horas da manhã e extraordinária era a concorrência no Boqueirão do Passeio. Tudo quanto a sociedade fluminense tem de mais chic lá estava, a fim de assistir ao certame daquela plêiade de moços". ${ }^{130}$ Um detalhe digno de destaque foi a realização de uma prova de 50 metros para alunos da escola de natação que o clube passou a oferecer aos sócios, juntamente com aulas de ginástica, esgrima e remo. ${ }^{131}$

Naquele momento algumas agremiações náuticas já ofereciam essas alternativas para seus associados. Cada vez mais se promovia a relação entre o

\footnotetext{
${ }^{126}$ Liberdade, $11 / 12 / 1896$, p. 2 ; O Paiz, 11/12/1896, p. 6.

${ }^{127}$ Cidade do Rio, 14/12/1896, p. 3.

${ }^{128}$ O Paiz, 14/12/1896, p. 2.

${ }^{129}$ Gazeta da Tarde, 07/01/1897, p. 2. No evento promovido em março de 1897, conseguiu-se organizar dois páreos de remo, dos quais tomaram parte atletas do Flamengo, Icaraí e Gragoatá.

${ }^{130}$ Cidade do Rio, 18/01/1897, p. 2.

${ }^{131} \mathrm{O}$ Paiz, 27/12/1897, p. 1.
} 
sport e a atividade física. ${ }^{132} \mathrm{~A}$ isso estava também associada uma maior aceitabilidade de exposição corporal, bem como a exibição pública de corpos mais musculosos e delineados. ${ }^{133}$

Os eventos do Clube de Natação, assim como ocorria com os de outras agremiações e modalidades esportivas, se articulavam com a efusiva dinâmica de entretenimentos da cidade, contando com a presença de gente de diversos estratos sociais. O frequente comparecimento de mulheres era muito celebrado. Se a principio não houve provas femininas, já se fez questão de registrar o nome daquelas que desempenharam uma função protagonista na organização das competições.

Deve-se ter em conta que isso não significou que todos os estratos sociais passaram a se dedicar à natação. Até mesmo entre as elites havia resistências à prática, ainda que o público fosse crescente nos eventos competitivos. Basicamente, dedicavam-se à modalidade jovens ligados aos novos setores urbanos, membros de famílias que atuavam no comércio, no pequeno setor industrial, nos negócios financeiros ou se destacavam como profissionais liberais.

As atividades do Clube de Natação, assim, eram ao mesmo tempo causa e consequência, sinal e protagonista de um conjunto de mudanças em curso na cidade. Não se tratava de competições nas mais distantes praias da zona sul, na Enseada de Botafogo, ou da região do Caju/São Cristóvão, mas sim bem no centro, onde já se tornara possível homens e mulheres se apresentarem mais à vontade, expressão de uma vida com menos rigores sociais, mais afeita a um estilo burguês. O colunista A. A., numa de suas palestras, publicadas em $O$ Paiz, encheu a agremiação de elogios, por seus serviços à saúde, segurança e fraternidade, a considerando como uma clara expressão de que avançavam os costumes da sociedade fluminense. ${ }^{134}$

É interessante perceber que o clube passou a promover melhorias na praia da Lapa, a fim de melhor acolher não somente os que vinham em dias de regatas, como também os que frequentavam cotidianamente sua sede. ${ }^{135}$ Na imagem a seguir, vemos o barracão da agremiação, ao lado do Passeio Público, na fronteira com a praia do Boqueirão do Passeio. Para que se tenha

\footnotetext{
${ }^{152}$ Para um debate sobre esse tema, ver: MELO, Victor Andrade de. Cidade sportiva: primórdios do esporte no Rio de Janeiro. Rio de Janeiro: Relume Dumará/Faperj, 2001.

${ }^{133}$ MELO, Victor Andrade de, 2011, op. cit.

${ }^{154} \mathrm{O}$ Paiz, 27/12/1887, p. 1.

${ }^{135} \mathrm{O}$ Paiz, 29/03/1897, p. 2.
} 
rev. hist. (São Paulo), n. 172, p. 299-334, jan.-jun., 2015 http://dx.doi.org/10.11606/issn.2316-9141.rh.2015.98755
Victor Andrade de Melo

Enfrentando os desafios do mar: a natação no Rio de Janeiro do século XIX (anos 1850-1890)

uma ideia, o prédio branco que se situa atrás da sede é do Silogeu Brasileiro, onde hoje está o prédio do Instituto Histórico e Geográfico Brasileiro.

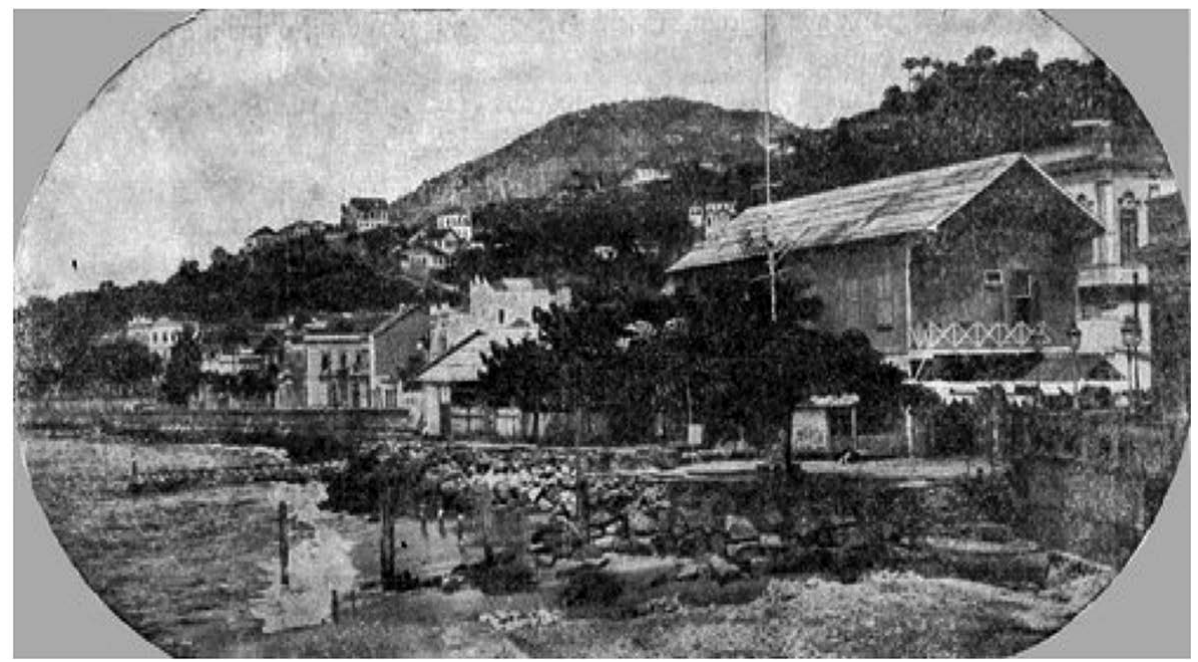

Sede do Clube de Natação

Nesse contexto, o Clube de Natação cada vez mais se relacionou com as outras agremiações, tomando parte nas ações coletivas entabuladas para fortalecer os esportes náuticos. Em 1897, seus dirigentes não compareceram ao encontro marcado para discutir a confecção de um código único de regatas, alegando não terem sido convidados. Logo, contudo, integraram o grupo, filiando-se, inclusive, tanto à União de Regatas Fluminense quanto ao futuro Conselho Superior de Regatas. ${ }^{136}$ A modalidade, portanto, se acolhia nas entidades do esporte que já estava mais bem delineado naquele fim de século, o remo.

A propósito, em 1897, a agremiação adquiriu embarcações para tomar parte nas competições de remo. ${ }^{137}$ Há indícios que sugerem que um grupo de remadores do Flamengo, por discordâncias internas, tenha para lá se transferido. Em função dessa nova adesão, em julho do mesmo ano, mudou seu nome para Clube de Natação e Regatas. ${ }^{138}$

\footnotetext{
${ }_{136}$ Para mais informações sobre essas associações, ver: MELO, Victor Andrade de, 2001, op. cit. 137 O Paiz, 08/04/1897, p. 3.

${ }^{138}$ Futuramente seria denominado Clube de Natação e Regatas Santa Luzia, quando se transferiu para a travessa do Maia. A agremiação segue ativa até os dias de hoje.
} 
Em 1898, o Clube promoveu eventos ainda mais organizados, culminando com a comemoração do seu $3^{\circ}$ aniversário, em dezembro. Numa "extraordinariamente chic" festa, ${ }^{139}$ contando com a presença de importantes personagens da sociedade fluminense, do corpo de associados e de representantes de boa parte dos clubes esportivos da cidade, além de grande público, foram realizados quatro páreos, o último chamado de "campeonato", com saída na ilha de Villegagnon e chegada no barracão da agremiação, um trajeto de 1.500 metros, disputado por seis nadadores; José Guimarães se sagrou vencedor.

Não se pode dizer que, no século XIX, se estabelecera na cidade definitivamente a natação como um esporte. Nos primeiros anos do século XX, a modalidade assistiria momentos ainda mais entusiasmantes. Surgiria um primeiro grande nome das competições, Abrahão Saliture, um dos maiores vencedores dos campeonatos brasileiros da prática promovidos pela Federação Brasileira de Sociedades de Remo a partir de 1901. Nas décadas seguintes, surgiriam novos "heróis das águas", vencedores de provas mais organizadas, disputadas por sócios de um número maior de agremiações.

De toda forma, já naquele século XIX, o Clube de Natação e Regatas comprovara que os páreos de nadadores poderiam ser emocionantes e atrair público, dando os primeiros passos mais sólidos na constituição da faceta esportiva da modalidade.

\section{Conclusão}

A conformação da prática da natação no Rio de Janeiro do século XIX esteve articulada com um conjunto de dimensões que ganharam força na sociedade da Corte naquele momento. Numa cidade que assumiu a centralidade num país que começava a definitivamente se consolidar como ente independente, o desenvolvimento do hábito se relacionou com preocupações com a melhor estruturação urbana e o forjar de novos comportamentos tidos como "civilizados".

A prática da natação, logo, se desenvolveu tanto a partir de estímulos diversos quanto se fazendo presente em distintos espaços sociais, adquirindo facetas diferentes, embora de forma alguma divergentes. Entre essas, encontra-se o delineamento de competições que anteciparam a consolidação do

\footnotetext{
${ }^{159} \mathrm{O}$ Paiz, 19/12/1898, p. 2. Esse campeonato foi realizado em outros anos. Ver, por exemplo, sobre a edição de 1899, vencida por Arnold Vogt, a matéria em Semana Sportiva, 23/12/1899, p. 2.
} 
seu formato esportivo, processo que também se deu no compartilhar de sentidos e significados com outras práticas esportivas, notadamente com o remo.

A peculiaridade dessa faceta era potencializar alguns dos aspectos que já vinham se manifestando ao redor da natação, entre os quais a adoção de novas posturas (o empreendedor obstinado pelos desafios e pelo progresso) que se articulavam com novas exibições corporais (corpo musculoso, saudável, higiênico, possibilidade denotada para homens, ainda que mulheres também tenham tomado parte no processo de vulgarização da modalidade) e com uma nova dinâmica de sociabilidade, marcada pela valorização da vida pública e do entretenimento.

Ainda não se tratava de uma modalidade vulgarizada pelos diferentes estratos sociais. De toda forma, a prática já entusiasmava muita gente, sendo mais um indicador da forte relação que se estava progressivamente a estabelecer entre os fluminenses e as praias, algo que inclusive determinaria a maior ocupação e valorização das moradias da zona sul do Rio de Janeiro.

\section{Referências bibliográficas}

BARICKMAN, B. J. O banho de mar no Rio de Janeiro no século XIX e no começo do século $X X$. Arizona: 2010.

BOURDIEU, Pierre. Como é possível ser esportivo? In: BOURDIEU, Pierre. Questões de sociologia. Rio de Janeiro: Marco Zero, 1983, p. 136-163.

BYINGTON, Carlos Amadeu Botelho. Dom Casmurro no divã: um estudo da psicologia simbólica junguiana. In: CARVALHO, Luiz Fernando. O processo de Capitu. Rio de Janeiro: Casa da Palavra, 2008.

CÂNDIDO, Francisco de Paula. Relatório do presidente da Junta Central de Hygiene Pública. In: BRASIL. Ministério do Império. Relatório do ano de 1858, apresentado à Assembleia geral legislativa na $3^{\mathrm{a}}$ sessão da $10^{\mathrm{a}}$ legislatura. (publicado em 1859). Rio de Janeiro: Ministério do Império, 1859, p. A-G-1 - A-G-17. Disponível em: <http://brazil.crl.edu/bsd/bsd/u1731/>. Acesso em: 17 set 2014.

CARULA, Karoline. Carlos Costa e A Mãe de Família: concepções acerca da maternidade em fins dos oitocentos. In: FERREIRA, Tânia Maria Tavares Bessone da Cruz; NEVES, Lucia Maria Bastos Pereira das; GUIMARÃES, Lucia Maria Paschoal. (org.). Elites, fronteiras e cultura do Império do Brasil. Rio de Janeiro: Contra Capa, 2013, p. 203-228.

CHALHOUB, Sidney. Cidade febril: cortiços e epidemias na Corte imperial. São Paulo: Companhia das Letras, 2006.

CORBIN, Alain. $O$ território do vazio. A praia e o imaginário ocidental. São Paulo: Companhia das Letras, 1989.

CRESTANI, Luís. O perfil editorial da revista A Estação: Jornal ilustrado para a família. Revista Anpoll, v. 1, n. 25, 2008, p. 325-353. 
DAY, Dave. "What girl will now remain ignorant of swimming?" Agnes Beckwith, aquatic entertainer and Victorian role model. Women's History Review, v. 21, n. 3, 2012, p. 419-443.

DIAS, Cléber Augusto. Epopeia em dias de prazer: uma história do lazer na natureza (17791838). Goiânia: UFG, 2013.

EDMUNDO, Luiz. O Rio de Janeiro do meu tempo. $2^{\text {a }}$ edição. Rio de Janeiro: Conquista, 1957.

FERREIRA, Luiz Otávio. Os periódicos médicos e a invenção de uma agenda sanitária para o Brasil (1827-43). História, Ciência, Saúde - Manguinhos, Rio de Janeiro, v. 6, n. 2, 1999, p. 331-351.

FINOCCHIO, José Luiz. A inserção da educação física/gymnastica no ensino secundário Imperial Collegio de Pedro II (1837-1889). Tese de doutorado em Educação, Universidade Federal de Mato Grosso do Sul, Campo Grande, 2013.

FLETCHER, James Cooley \& KIDDER, Daniel Parish. O Brasil e os brasileiros: esboço histórico e descritivo. Rio de Janeiro: Companhia Editora Nacional, 1941.

GIULIANOTTI, Richard (org.). Sport and modern social theorists. Nova York: Palgrave Macmillan, 2004.

LIMA, Joelma Varão. Jornal das Senhoras: as mulheres e a urbanização na Corte. Cadernos Ceru, São Paulo, v. 21, n. 2, 2010, p. 227-240.

LOVE, Christopher. A social history of swimming in England, 1800 - 1918: splashing in the serpentine. Londres: Routledge, 2007.

LUCA, Tania Regina de. História do, no e por meio dos periódicos. In: PINSKY, Carla Bassanezi (org.). Fontes históricas. São Paulo: Contexto, 2005, p. 111-53.

MARCILIO, Maria Luiza. Mortalidade e morbidade da cidade do Rio de Janeiro imperial. Revista de História, São Paulo, n. 127-128, ago-dez 1992; jan-jul 1993, p. 53-68.

MARROCOS, Luís Joaquim dos Santos. Cartas do Rio de Janeiro - 1811-1821. Lisboa: Biblioteca Nacional de Portugal, 2008.

MARZANO, Andrea $\mathcal{E}$ MELO, Victor Andrade de. Vida divertida: histórias do lazer no Rio de Janeiro (1830 - 1930). Rio de Janeiro: Apicuri, 2010.

MELO, Victor Andrade de. Cidade sportiva: primórdios do esporte no Rio de Janeiro. Rio de Janeiro: Relume Dumará/Faperj, 2001.

O corpo esportivo nas searas tupiniquins: um panorama histórico. In: AMANTINO, Marcia E PRIORE, Mary Del. (org.). História do corpo no Brasil, v. 1. São Paulo: Editora da Unesp, 2011, p. 123-145.

"Temos apaixonados para o mar e para a terra": representações do esporte nos folhetins (Rio de Janeiro; 1851-1855). Revista Brasileira de Educação Física e Esporte, São Paulo, v. 27, n. 4, 2013, p. 553-566.

MELO, Victor Andrade de $\mathcal{E}$ PERES, Fabio de Faria. A gymnastica nos tempos do Império. Rio de Janeiro: 7 Letras/Faperj, 2014.

NEEDELL, Jeffrey D. Belle Époque tropical. São Paulo: Companhia das Letras, 1993.

POMPEIA, Raul. Crônicas do Rio. Rio de Janeiro: Secretaria Municipal de Cultura, 1996.

POPINIGIS, Fabiane. Proletários de casaca: trabalhadores do comércio carioca (1850-1911). Campinas: Editora da Unicamp, 2007. 
PORTER, Roy. Os ingleses e o lazer. In: CORBIN, Alain (org.). História dos tempos livres. Lisboa: Teorema, 2001, p. 19-58.

RAUCH, André. As férias e a natureza revisitada. In: CORBIN, Alain (org.). História dos tempos livres. Lisboa: Teorema, 2001, p. 91-136.

RIO, João do. Pall-Mall Rio de José Antonio José. Inverno mundano de 1916. Rio de Janeiro: Editores Villas-Boas \& C., 1917.

SCHWARCZ, Lilia Moritz. As barbas do imperador. São Paulo: Companhia das Letras, 1998.

TERRET, Thierry. Naissance et diffusion de la natation sportive. Paris: L'Harmattan, 1994.

TOUSSAINT-SAMSON, Adèle. Uma parisiense no Brasil. Rio de Janeiro: Editora Capivara, 2003.

VIGARELLO, Georges. O limpo e o sujo. A higiene do corpo desde a Idade Média. Lisboa: Fragmentos, 1988.

Recebido: 12/10/2014 - Aprovado: 26/02/2015 